\title{
De weg van nazorg naar voorzorg: buiten de gebaande paden
}

Citation for published version (APA):

Ruwaard, D. (2012). De weg van nazorg naar voorzorg: buiten de gebaande paden. Maastricht University. https://doi.org/10.26481/spe.20120420dr

Document status and date:

Published: 20/04/2012

DOI:

$10.26481 /$ spe.20120420dr

Document Version:

Publisher's PDF, also known as Version of record

\section{Please check the document version of this publication:}

- A submitted manuscript is the version of the article upon submission and before peer-review. There can be important differences between the submitted version and the official published version of record.

People interested in the research are advised to contact the author for the final version of the publication, or visit the DOI to the publisher's website.

- The final author version and the galley proof are versions of the publication after peer review.

- The final published version features the final layout of the paper including the volume, issue and page numbers.

Link to publication

\footnotetext{
General rights rights.

- You may freely distribute the URL identifying the publication in the public portal. please follow below link for the End User Agreement:

www.umlib.nl/taverne-license

Take down policy

If you believe that this document breaches copyright please contact us at:

repository@maastrichtuniversity.nl

providing details and we will investigate your claim.
}

Copyright and moral rights for the publications made accessible in the public portal are retained by the authors and/or other copyright owners and it is a condition of accessing publications that users recognise and abide by the legal requirements associated with these

- Users may download and print one copy of any publication from the public portal for the purpose of private study or research.

- You may not further distribute the material or use it for any profit-making activity or commercial gain

If the publication is distributed under the terms of Article $25 \mathrm{fa}$ of the Dutch Copyright Act, indicated by the "Taverne" license above, 


\section{Maastricht University}

\section{Prof.dr. Dirk Ruwaard}

Faculty of Health, Medicine and Life Sciences

\section{De weg van nazorg naar voorzorg: buiten de gebaande paden}

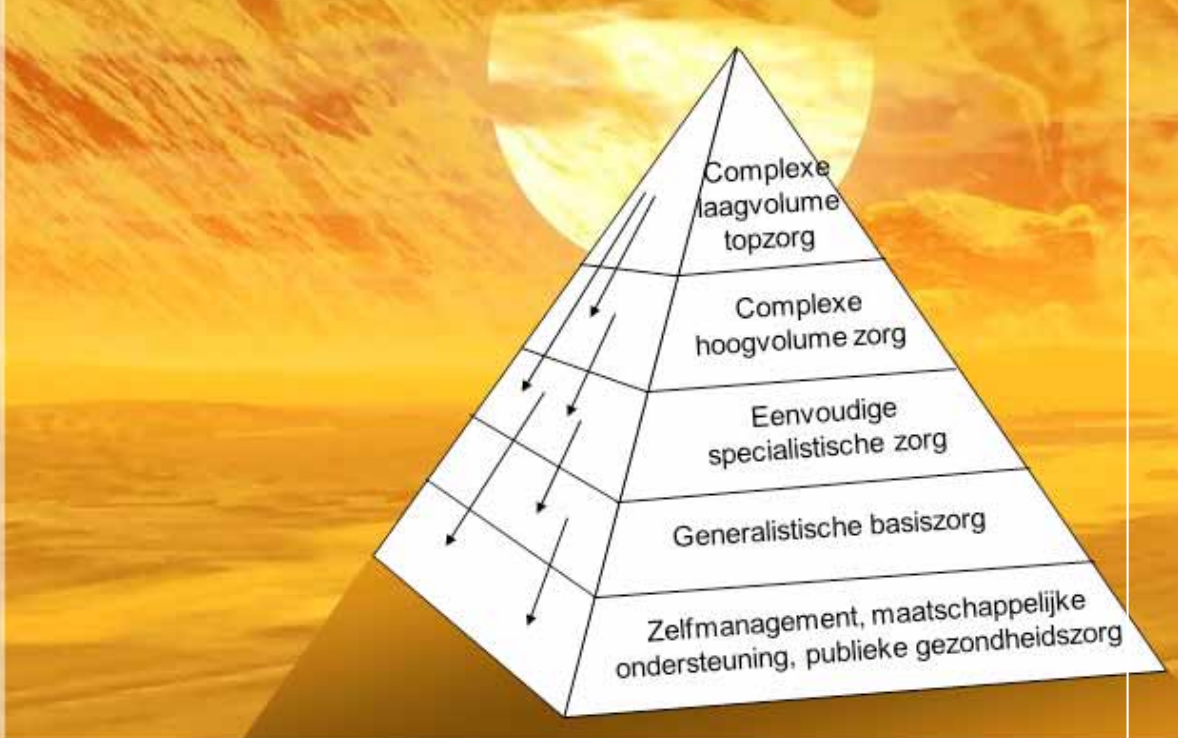


De weg van nazorg naar voorzorg:

buiten de gebaande paden 


\section{Colofon}

Ontwerp en print: Océ Business Services, Maastricht

Illustratie op kaft: Op basis van de publicatie 'Zorg en ondersteuning in de buurt'. Den Haag: Ministerie van VWS, 2011. Bewerkt door mw. S. Koene

(http://www.rijksoverheid.nl/documenten-en-publicaties/kamerstukken/2011/10/14/ kamerbrief-zorg-en-ondersteuning-in-de-buurt.html; geraadpleegd op 17 maart 2012)

ISBN: 978-90-5681-385-7

NUR: 870

Alle rechten voorbehouden. Niets uit deze uitgave mag worden verveelvoudigd, opgeslagen in een geautomatiseerd gegevensbestand of openbaar gemaakt worden, zonder voorafgaande schriftelijke toestemming van de auteur of uitgever. 


\section{De weg van nazorg naar voorzorg: buiten de gebaande paden}

\section{Rede}

In verkorte vorm uitgesproken bij de aanvaarding van het ambt van hoogleraar Public Health and Health Care Innovation aan de Faculty of Health, Medicine and Life Sciences van de

Universiteit Maastricht

Maastricht, 20 april 2012

Prof.dr. Dirk Ruwaard 
Mijnheer de Rector Magnificus, Leden van het College van Bestuur van de Universiteit Maastricht, Leden van de Raad van Bestuur van het Maastricht Universitair Medisch Centrum+, Zeer gewaardeerde collega's, Beste familie, vrienden en overige toehoorders.

Om maar direct met de deur in huis te vallen, mijn stelling is dat het huidige zorgstelsel in de toekomst financieel onhoudbaar is. De titel van mijn rede luidt niet voor niets: 'De weg van nazorg naar voorzorg: buiten de gebaande paden'. Mijn ambitie is om vanuit mijn leerstoel in samenwerking met anderen initierend en faciliterend te zijn naar het zoeken van wegen om ook in de toekomst betaalbare en kwalitatief hoogwaardige zorg te blijven garaderen. $\mathrm{k}$ zal dat in deze rede nader motiveren en toelichten.

\section{Ziekte en gezondheid: het begrippenkader}

Mijn motief om eind jaren zeventig te starten met de studie geneeskunde was om een ziek persoon, een patiënt dus, gezond te maken. Dat zal u niet verbazen. De eerste door ons gepubliceerde Volksgezondheid Toekomst Verkenning uit 1993 opent ook met de zin: 'Een goede gezondheid wordt door steeds meer Nederlanders gewaardeerd als het belangrijkste in het leven' (Ruwaard \& Kramers, 1993). De meest recente Volksgezondheid Toekomst Verkenning uit 2010, 17 jaar later, meldt dat de meeste burgers hun gezondheid het allerbelangrijkst vinden (Van der Lucht \& Polder, 2010). Gezondheid houdt ons bezig. Of het nu gaat om uw eigen gezondheid, die van uw familie, vrienden en collega's of die van de bevolking als geheel.

Er zijn veel definities en omschrijvingen van het begrip gezondheid. Ik noem die van de Wereldgezondheidsorganisatie die in 1948 werd geïntroduceerd: 'Health is a state of complete physical, mental and social-well being, and not merely the absence of disease or infirmity'. Met andere woorden, je bent nog niet gezond als je geen ziekte hebt, want bijvoorbeeld ook het maatschappelijk welbevinden dient optimaal te zijn. Er is de nodige kritiek geweest op de reikwijdte van deze definitie. lemand kan immers objectiveerbaar een ziekte onder de leden hebben, maar zich toch gezond voelen. Er is dus ook een duidelijk subjectief element aanwezig, namelijk hoe wij onze gezondheid ervaren. Soms wordt ook een verschil gemaakt in verschillende vormen van ziekte of ongezondheid aan de hand van de 
Engelse termen: disease vanuit het medisch perspectief, illness vanuit het subjectieve perspectief en sickness vanuit het sociale perspectief (Van den Heuvel, 1989).

De Gezondheidsraad en ZonMw hebben zich recent opnieuw gebogen over de definitie van gezondheid en daar een internationale conferentie aan gewijd (Gezondheidsraad, 2010). Afgelopen jaar is de uitkomst daarvan ook gepubliceerd in de British Medical Journal (Huber et al., 2011). Eén van de constateringen is dat gezondheid niet statisch maar dynamisch is. De zinsnede 'Health is a state of ...' in de definitie van de Wereldgezondheidsorganisatie suggereert een toestand, terwijl gezondheid dynamisch is. We vinden dat ook terug in de Nota 2000 van het voormalige ministerie van Welzijn, Volksgezondheid en Cultuur (WVC, 1986) en andere pubicaties (Ten Have, 1987; Van Dijk et al, 1990; Ruwaard \& Kramers. 1993). Gezondheid kan worden gezien als een situatie van evenwicht, die wordt bepaald door de omstandigheden waarin mensen verkeren en het vermogen dat zijzelf bezitten, of zich met behulp van anderen kunnen verwerven, om zich te verweren tegen verstoringen. Het begrip ziekte of ongezondheid impliceert dan het uit balans zijn of niet naar behoren of naar wens functioneren.

Verder constateren de Gezondheidsraad en ZonMw dat de invulling van de definitie afhankelijk is van de context. Ik zal dat nader illustreren. Toen ik als co-assistent voor mijn eerste coschap startte bij interne geneeskunde, was ik sterk gefocust op het diagnosticeren van een lichamelijke ziekte die zou kunnen passen bij de symptomen waarmee de patiënt zich presenteerde. Maar bij het coschap psychiatrie lag de focus op het diagnoticeren van een psychische aandoening. Bij de invulling van de Wet maatschappelijke ondersteuning (Wmo) onder verantwoordelijkheid van de gemeente zal vooral de participatie en daarmee het maatschappelijk welbevinden van de burger centraal staan.

De les die ik eruit geleerd heb, is dat de problemen waarmee een patiënt of burger zich presenteert sterk gefragmenteerd worden benaderd. De vraag is of diezelfde patiënt of burger daar nu wel het beste mee geholpen is. Zal een behandeling niet beter aanslaan als we meer inzicht hebben in en handelen juist en vooral vanuit de totale context van die patiënt of burger in plaats vanuit de context van de zorgverlener? 


\section{Een conceptueel model voor de volksgezondheid}

Om inzicht te krijgen in de gezondheid van de bevolking, de volksgezondheid dus, en de mogelijkheden voor beïnvloeding daarvan is in het kader van de Volksgezondheid Toekomst Verkenning door ons destijds een conceptueel model ontwikkeld (Ruwaard \& Kramers, 1993). Dit model kan in iets aangepaste vorm nog steeds als uitgangspunt van ordening dienen (Hollander et al., 2006). Figuur 1 illustreert.

Figuur 1: Conceptueel basismodel van de volksgezondheid

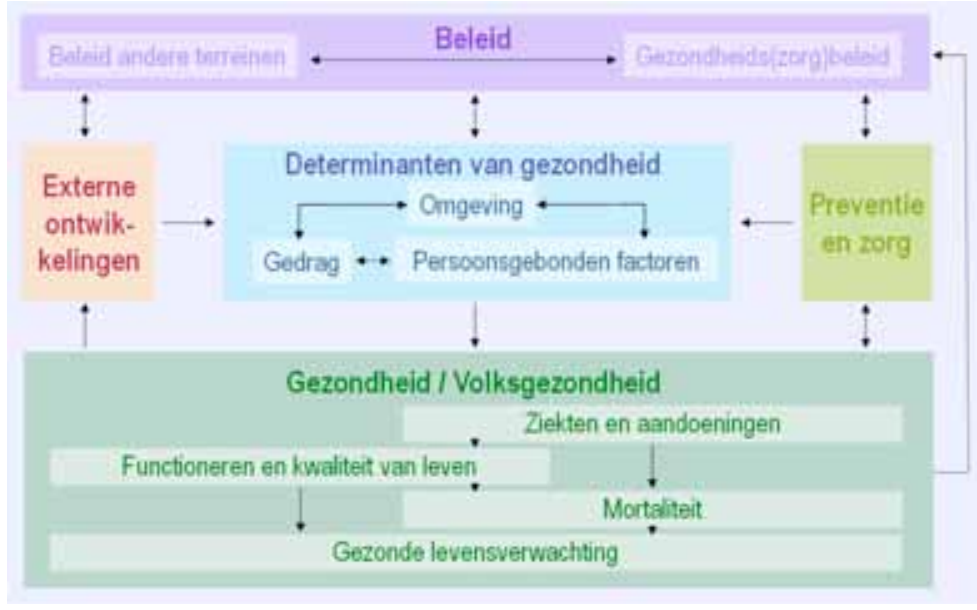

Bron: vrij naar Den Hollander et al., 2006

Indicatoren van gezondheid

Om recht te doen aan de verschillende aspecten van het brede begrip gezondheid, zoals hier weergegeven in het onderste blok, wordt een variatie aan indicatoren gebruikt om de gezondheid en daarmee de volksgezondheid in beeld te brengen. Denk bijvoorbeeld aan ziektespecifieke indicatoren, zoals hoe vaak diabetes mellitus in de bevolking voorkomt. Maar het gaat ook om maten die iets zeggen over wat de gevolgen van ziekten zijn voor het functioneren en de kwaliteit van leven. Let wel dat het functioneren en de kwaliteit van leven deels onafhankelijk zijn van het al dan niet optreden van ziekten. Ook zonder de aanwezigheid van een ziekte of diagnose kan de gezondheid als slecht worden ervaren, zoals al eerder gemeld. Ook de mortaliteit of sterfte is een indicator. Verschillende indicatoren kunnen ook 
gecombineerd gebruikt worden in één samengestelde maat, bijvoorbeeld de 'gezonde levensverwachting', 'ongezonde levensverwachting' en 'Disability Adjusted Life Years'. Ik kom daar straks op terug.

\section{Determinanten van gezondheid}

Factoren die van invloed zijn op de gezondheid en daarmee de volksgezondheid zijn hier gedefinieerd als determinanten van gezondheid. Zij vormen het middelste blok van de middelste laag. Voorbeelden hiervan zijn ons gedrag zoals roken, eten, bewegen, maar ook de omgeving waarin we leven, zoals de blootstelling aan milieuverontreiniging (fysieke omgeving) of het deel uitmaken van sociale netwerken (sociale omgeving). Ook persoonsgebonden factoren zijn eigenschappen van mensen die aangeboren zijn dan wel verworven gedurende het leven. Voorbeelden hiervan zijn geslacht, erfelijke aanleg, persoonlijkheid, bloeddruk en gewicht. Deze groepen van determinanten staan niet los van elkaar maar kunnen elkaar ook beïnvloeden. Zo leidt veel eten en weinig bewegen in een omgeving die ons niet uitdaagt gezond te leven tot overgewicht.

\section{Determinanten van determinanten}

In figuur 1 zijn in de middelste laag nog twee blokken toegevoegd: preventie en zorg aan de rechterkant en externe ontwikkelingen aan de linker kant. Zoals de pijlen aangeven, kunnen deze blokken weer van invloed zijn op de determinanten van gezondheid. Het zijn dan de determinanten van de determinanten, oftewel, de meer distale determinanten. Via preventieve maatregelen wordt beoogd het gedrag te beïnvloeden. Denk aan campagnes om te stoppen met roken. Maar ook het aanpassen van de omgeving door het voedsel veilig te maken of het beïnvloeden van persoonsgebonden factoren via het Rijksvaccinatieprogramma zijn voorbeelden van preventieve maatregelen. Zorg kan zowel via de determinanten lopen met als voorbeeld het gebruik van geneesmiddelen voor te hoge bloeddruk als persoonsgebonden factor of direct van invloed zijn op de gezondheid, bijvoorbeeld via chirurgische ingrepen. Bij de externe ontwikkelingen gaat het om ontwikkelingen die zich buiten het gezondheidsdomein afspelen maar via de determinanten wel invloed hebben op de gezondheid. Hierbij kan gedacht worden aan demografische, economische, sociaal-culturele en technologische ontwikkelingen. Op die demografische ontwikkelingen kom ik straks uitvoeriger terug. Laat ik u een voorbeeld geven van het effect van economische ontwikkelingen op de volksgezondheid. Uit retrospectief onderzoek over de periode 1960-2002 blijkt dat een financiële crisis bij banken heeft geleid tot een toename van de sterfte aan hartzieken in ontwikkelde landen maar in nog sterkere mate in ontwikkelingslanden (Stuckler et al., 2008). Ook de recente crisis in Griekenland laat zien dat 
de toegankelijkheid van de zorg afneemt met duidelijke signalen van achteruitgang van de volksgezondheid (Kentikelenis et al., 2011).

Beleid

De bovenste laag in de figuur vertegenwoordigt het beleid. Hier kan nog een onderscheid gemaakt worden in het beleid van de overheid, koepelorganisaties, zorginstellingen en andere actoren dat tot doel heeft om gezondheidsproblemen te vóórkomen, te herstellen, verergering tegen te gaan dan wel te verzorgen en verplegen, het zogenaamde gezondheids(zorg) beleid. Onder beleid op andere terreinen wordt verstaan het beleid dat buiten de strikte volksgezondheidssfeer valt, maar waar toch sprake is van het voorkomen van gezondheidsschade (bijv. verkeersveiligheidsbeleid, onderwijsbeleid, werkgelegenheidsbeleid). Van oudsher wordt dat ook wel aangeduid met facetbeleid of intersectoraal beleid.

Waarom sta ik hier nu zo bij stil? Omdat ik het voorrecht gehad heb om tijdens mijn loopbaan ook breder te kijken dan de zorg in engere zin. Je werd als arts toch vooral opgeleid om een patiënt beter te maken. Maar echt aandacht voor preventie was er niet, laat staan het besef dat er buiten het zorgdomein ook mogelijkheden zijn om de volksgezondheid te verbeteren.

\section{Ontwikkelingen in de volksgezondheid}

Met het conceptuele model als leidraad geef ik $u$ hierbij een doorkijk in hoe gezond of ongezond de bevolking in Nederland is, welke determinanten daarbij een rol spelen en wat daarvan de ontwikkelingen in de tijd zijn.

Indicatoren van gezondheid

Om inzicht te krijgen in de ziektelast op bevolkingsniveau wordt wel de samengestelde maat 'Disability-Adjusted Life Years (DALY)' gebruikt. Deze maat combineert het vóórkomen van een ziekte rekening houdend met de duur en ernst ervan om een beeld te krijgen van het verlies aan gezonde jaren tijdens het leven (verlies aan jaren in gezondheid) mét het aantal jaren dat we eerder overlijden als gevolg van die ziekte (verloren levensjaren door overlijden). Tabel 1 geeft de top-10 ziekten die verantwoordelijk zijn voor de meeste ziektelast in Nederland in 2007. 
Tabel 1: Top-10 ziekten met de meeste ziektelast in 2007 in Nederland naar geslacht

\begin{tabular}{llll}
\hline Mannen & \% van ziektelast & Vrouwen & \% van ziektelast \\
& & & \\
\hline Coronaire hartziekten & 13,7 & Angststoornissen & 8,2 \\
Beroerte & 6,8 & Coronaire hartziekten & 7,7 \\
Longkanker & 6,3 & Beroerte & 7,4 \\
Diabetes mellitus & 5,7 & Depressie & 7,1 \\
COPD & 5,4 & Diabetes mellitus & 5,5 \\
Angststoornissen & 5,3 & Borstkanker & 5,3 \\
Depressie & 4,1 & Arthrose & 5,1 \\
Suïcide en suïcidepoging & 3,5 & Dementie & 4,7 \\
Privé ongevallen & 3,4 & COPD & 4,5 \\
Arthrose & 3,1 & Longkanker & 4,4 \\
\end{tabular}

Bron: Hoeymans et al., 2010 (op basis van de VTV-geselecteerde ziekten)

Wat opvalt is dat bijna alle ziekten chronisch zijn. Op zich is dat ook niet verwonderlijk want aan de hand van een selectie van 30 chronische ziekten gemeten in de huisartspraktijk telt Nederland minimaal 4,5 miljoen chronisch zieken (Hoeymans \& Schellevis, 2011) op een totale bevolking van ruim 16,5 miljoen. Van de hele Nederlandse bevolking heeft $8 \%$ meer dan één chronische ziekte, wat neerkomt op ruim 1,3 miljoen mensen. We spreken dan ook wel van multimorbiditeit.

Figuur 2 geeft de afhankelijkheid aan van het vóórkomen van een of meerdere chronische ziekten met de leeftijd. Naarmate we ouder worden zien we dat meer mensen een chronische aandoening krijgen, maar ook vaker meer dan één. Zo blijkt van de 75-plussers dat al ruim de helft een chronische ziekte heeft en zelfs één op de drie meer dan één.

Figuur 2: Het voorkomen van chronische ziekten op verschillende leeftijden

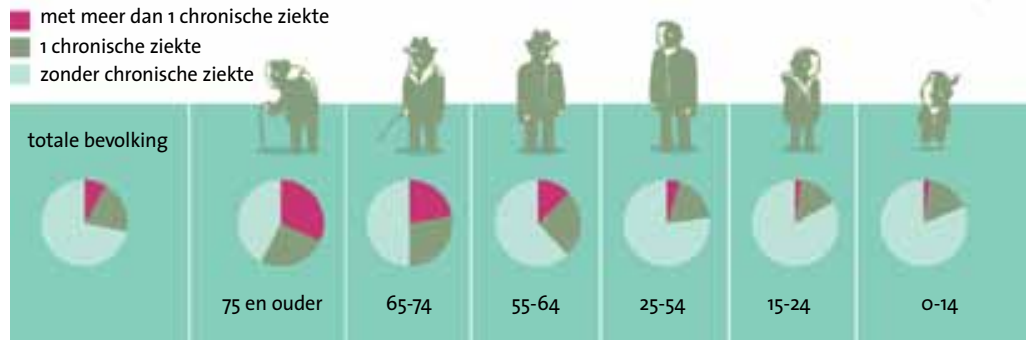


Bij een gemiddelde levensverwachting van 80 jaar blijkt dat 45 jaar daarvan wordt doorgebracht zonder chronische ziekten, terwijl de als goed ervaren gezonde levensverwachting op 64 jaar ligt en de levensverwachting zonder lichamelijke beperkingen op 70 jaar. Blijkbaar ervaren niet alle chronisch zieken een slechtere gezondheid of lichamelijke beperkingen. Dit geeft ook aan dat het begrip gezondheid diverse dimensies kent.

Desalniettemin zien we dat veel van de ongezondheid in Nederland en de gevolgen van ziekten voor het dagelijks functioneren en het maatschappelijk meedoen bij chronisch zieken te vinden is. In totaal is zo'n $70 \%$ van de ervaren ongezondheid toe te schrijven aan het hebben van een chronische ziekte. Ook hebben mensen met een chronische ziekte of beperking minder vaak betaald werk en een inkomen dat eenderde lager ligt dan het gemiddelde inkomen (Van den Brink-Muinen et al., 2009). In de meest recente Volksgezondheid Toekomst Verkenning van 2010 (Van der Lucht \& Polder, 2010) wordt dan ook gesteld dat het leven met een chronische ziekte een baan op zich is. Indien sprake is van multimorbiditeit, dus meerdere ziekten bij één individu, dan zijn de gevolgen alleen maar groter, met meer beperkingen en een lagere kwaliteit van leven. Datzelfde geldt als we chronisch zieken vergelijken met een verschillende sociaal-economische status: hoe lager die is, des te meer gevolgen de chronisch zieke ondervindt. Mensen met een lagere opleiding hebben meer gezondheidsproblemen en overlijden zelfs 6-7 jaar eerder dan hoog opgeleide mensen. Die verschillen zijn nog veel groter als we kijken naar de als goed ervaren gezondheid; laagopgeleide mannen en vrouwen leven respectievelijk 19,2 en 20,6 jaar minder in als goed ervaren gezondheid dan hoogopgeleide mannen en vrouwen (Bruggink et al., 2011).

\section{Determinanten van gezondheid}

Het aantal mensen met chronische ziekten neemt toe. Dat kent verschillende oorzaken en daarmee beland ik bij de invloed van belangrijke determinantgroepen op het vóórkomen van chronisch zieken en chronische ziekten in de bevolking.

De Volksgezondheid Toekomst Verkenning van 2010 (Van der Lucht \& Polder, 2010) laat overduidelijk zien dat voor tal van ongezonde leefstijlfactoren de blootstelling in de bevolking hoog is. Zo blijkt bijvoorbeeld dat vergeleken met de ons omringende landen veel Nederlanders roken; $27 \%$ van alle Nederlanders van 15 jaar en ouder rookt weleens of dagelijks. Zo'n 40-50\% van de Nederlanders heeft overgewicht, waarvan een kwart obesitas, 
als gevolg van teveel eten en/of te weinig bewegen. Slechts de helft voldoet aan de norm voor gezond bewegen en nog minder voldoen aan de richtlijnen goede voeding. Gelukkig constateert de Volksgezondheid Toekomst Verkenning ook dat de leefstijl van de Nederlanders zich in gunstige zin lijkt te ontwikkelen waarbij het eerder gaat om een stabilisatie en geen verdere toename. Recente cijfers van Stivoro wijzen overigens uit dat in 2011 het percentage rokers is gedaald naar $25 \%$, hetgeen nog steeds hoog is ook vergeleken met de ons omringende landen (Stivoro, 2012).

Nu hoeven we ons vanuit gezondheidsperspectief niet druk te maken om die leefstijl als er geen relatie is met de gezondheid van mensen, maar dat is helaas niet zo. Zo blijkt bijvoorbeeld dat rokers ruim vier jaar minder lang leven en er ruim viereneenhalf jaar verlies is aan gezonde levensjaren. Voor mensen met obesitas is dat respectievelijk drie en ruim vijf jaar. Dat is ook niet verwonderlijk want het zijn juist ook die leefstijlfactoren die verantwoordelijk zijn voor het ontstaan van meerdere chronische ziekten. Denk daarbij aan hart- en vaatziekten, diabetes mellitus, longziekten. Bovendien zien we dat ongezonde leefstijlfactoren ook nog clusteren. Bij volwassenen zie je clustering van roken met ongezond eten, te weinig bewegen en excessief alcoholgebruik. Hierbij speelt de sociaal-economische status ook een rol; meer ongezonde leefstijl bij lagere sociaal-economische status.

Ons eigen gedrag kan daarmee een belangrijke oorzaak zijn van de toename in het aantal chronisch zieken en ziekten. Maar die toename is niet alleen het gevolg van ons gedrag. Ook andere factoren spelen een rol. Omdat chronische ziekten toenemen met de leeftijd speelt ook, als een van de externe ontwikkelingen uit het eerder getoonde model, vergrijzing als gevolg van de naoorlogse geboortegolf een rol. Vorig jaar vierde de eerste lichting babyboomers hun 65ste verjaardag en het aandeel $65+$-ers in de bevolking zal als gevolg hiervan fors toenemen. In aanvulling hierop is het opzienbarend om te constateren dat de levensverwachting vooral in de periode 2002-2010 sterk steeg voor zowel mannen als vrouwen; voor mannen steeg die met 2,8 jaar naar 78,8 jaar en voor vrouwen met 2,0 jaar naar 82,7 jaar. Deze stijging is voor een groot deel het gevolg van het afgenomen risico om aan een hart- of vaatziekte te overlijden (Poos, 2011). Hierbij mag verondersteld worden dat men vanwege medischetechnologische ontwikkelingen met betere behandelingen langer blijft leven met ziekten (blok 'Zorg en preventie'). Dat is dus een verdienste. Het CBS voorspelt overigens een verdere toename in levensverwachting. Al met 
al is de meest recente prognose van het CBS dat op het hoogtepunt van de vergrijzing rond 2040, 26\%, dus meer dan 1 op 4 mensen in Nederland, 65 jaar of ouder zal zijn tegenover 1 op de 7 (15\%) in 2010 (Van Duin \& Garssen, 2011). Bovendien zal door vroegere opsporing bij meer mensen eerder in het leven een chronische ziekte gediagnosticeerd worden.

Figuur 3 toont de verwachte procentuele toename van het aantal chronische ziekten in de periode 2005-2025, waarin naast de invloed van de vergrijzing ook andere invloeden zijn meegenomen. Het effect van overgewicht op het ontstaan van diabetes ziet $u$ hier helemaal links. Het rookgedrag van vrouwen uit het verleden ziet $u$ hier vertaald naar de duidelijk sterkere toename van het aantal gevallen van longkanker onder vrouwen (ca. 80\%) ten opzichte van mannen (ca. 40\%). De sterke toename van hartfalen onder mannen is mede het gevolg van betere zorg omdat mensen met een hartinfarct langer blijven leven (Blokstra \& Verschuren, 2007). Er zijn overigens recente aanwijzingen dat voor enkele aandoeningen de verwachte toename groter zal zijn.

Figuur 3: Verwachte procentuele toename van het aantal chronische ziekten in de periode 2005-2025

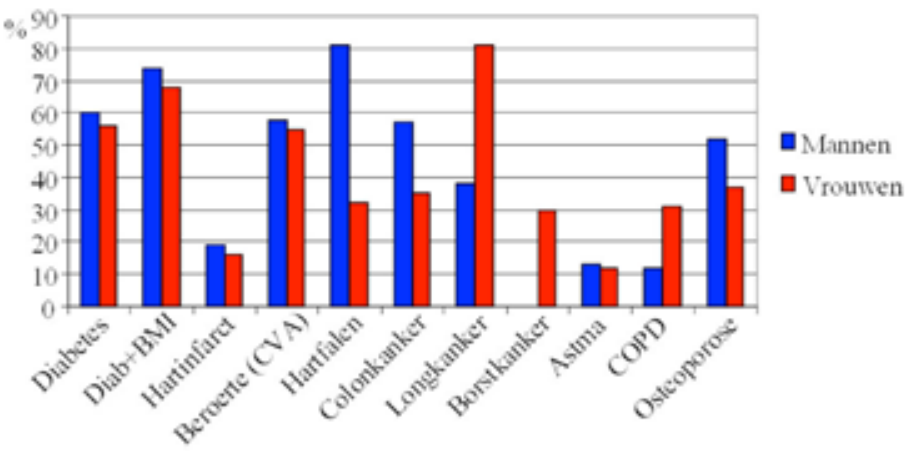

Bron: Blokstra \& Verschuren, 2007

Gelukkig zien we dat ondanks de toename van het aantal chronisch zieken en ondanks de afname het deel van het leven dat wij zonder chronische ziekten doorbrengen, de levensverwachting toenemen. De extra levensjaren die er recent zijn bijgekomen worden grotendeels in goede gezondheid en zonder lichamelijke beperkingen doorgebracht. Verklaringen hiervoor zijn dat bij vroege opsporing van ziekten mensen nog weinig of geen klachten hebben, ook al worden ze dan als chonisch ziek bestempeld, en een eerdere behandeling en verdergaande verbetering in de behandeling achteruitgang in gezondheid voorkomen. 
Indicatoren en determinanten van gezondheid in Zuid-Limburg Omdat het Maastricht UMC+ gelocaliseerd is in Zuid-Limburg, zijn een aantal woorden op zijn plaats om $u$ enig inzicht te geven in de indicatoren en determinanten van gezondheid in deze regio. In vergelijking met de rest van Nederland is de mortaliteit of sterfte als indicator van de gezondheid in Zuid-Limburg opvallend hoog en de ervaren gezondheid laag. Figuur 4 illustreert dat. Ook het voorkomen van hartinfarct en beroerte is hoger (www.zorgatlas.nl). Over het algemeen kan gesteld worden dat de gezondheid in Zuid-Limburg slechter is dan in de rest van Nederland. Ten aanzien van de determinanten van gezondheid blijkt de prevalentie of het vóórkomen van risicofactoren in Zuid-Limburg hoog. Figuur 5 laat dat zien voor roken en ernstig overgewicht (obesitas) als belangrijke risicofactoren voor chronische ziekten.

Figuur 4: Verschillen in sterfte, minder ervaren gezondheid en beroerte naar GGD-regio in Nederland
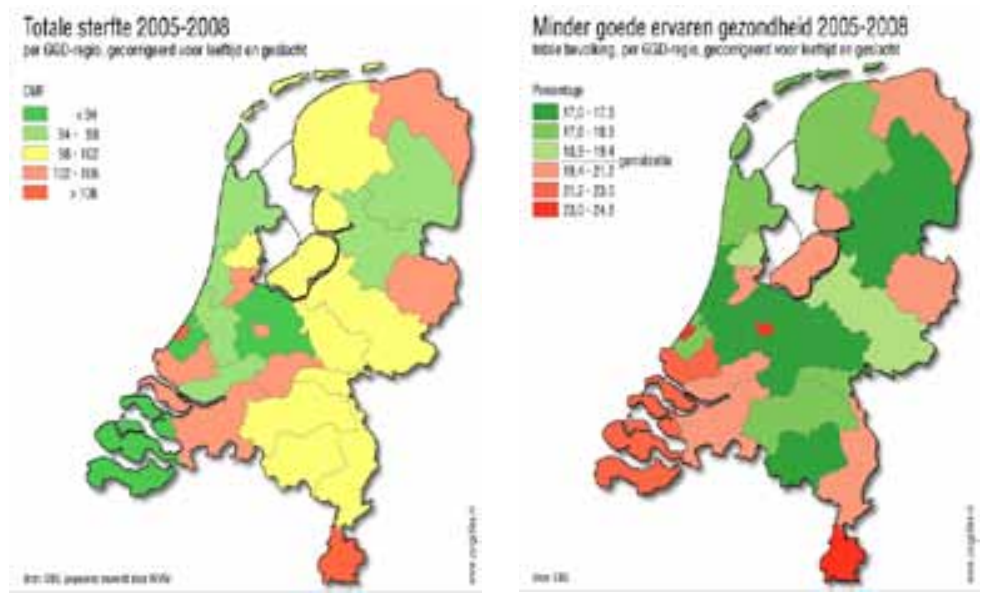

Bron: www.zorgatlas.nl 
Figuur 5: Verschillen in het percentage rokers en personen met obesitas naar GGD-regio in Nederland
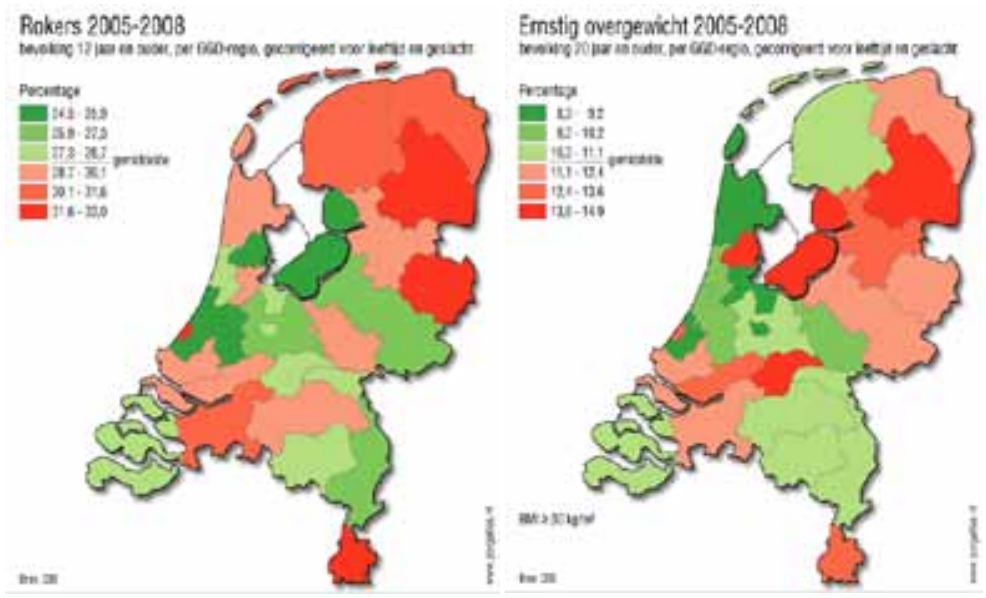

Bron: www.zorgatlas.nl

Maar ook de vergrijzing en ontgroening gaan in Zuid-Limburg sneller dan elders in Nederland. In Zuid- en Midden Limburg zal rond 2025 al meer dan een kwart van de bevolking 65-plusser zijn. Hiervan is gemiddeld genomen in heel Nederland pas sprake rond 2040 (Garssen, 2011). Tevens zien we dat de regio Parkstad in Zuid-Limburg voor het eerst in Nederland al sinds 1998 te maken heeft met een afnemende bevolkingsomvang, ook wel demografische krimp genoemd. Voor Nederland als geheel is hiervan pas sprake vanaf 2035. Opvallend is dat na correctie voor leeftijd en sociaaleconomische status er onverklaarbare verschillen blijven bestaan tussen deze regio en de rest van Nederland (Verweij \& Van der Lucht, 2011).

\section{Maatschappelijke uitdagingen}

Zoals gezegd zal als gevolg van meerdere oorzaken het aantal ouderen en chronisch zieken in de toekomst toenemen. Dit zal zonder extra maatregelen vergaande consequenties hebben voor de zorg op de lange termijn. Ik noem er hier vier.

\section{Complexere zorgvraag vraagt om herbezinning huidige zorgaanbod}

Ten eerste zal de zorgvraag veranderen. De toename van het aantal ouderen en chronisch zieken met een groeiend aandeel mensen met meer dan 
één aandoening (multimorbiditeit) vergt een andere organisatie van het zorgaanbod. Meer nog dan bij enkelvoudige chronische aandoeningen is een geïntegreerde en multidisciplinaire aanpak noodzakelijk. Wanneer we dit plaatsen in een tijd waarin zorg op maat op basis van de persoonlijke behoeften en persoonlijke voorkeuren van de patiënt/cliënt een steeds grotere rol zal gaan spelen, terwijl tegelijkertijd een vergroting van de participatie en zelfredzaamheid aspecten zijn die belangrijker worden ten koste van het repareren van aandoeningen, dan versterkt dat de behoefte aan een herbezinning van het huidige zorgaanbod.

Meer zorgvraag met stijgende zorguitgaven vraagt om keuzes in de zorg Ten tweede zal de toename in het aantal patiënten met één of meerdere chronische ziekten zonder meer consequenties hebben voor de uitgaven in de zorg. Figuur 6 laat zien dat in de periode 1985-2009 Nederland bij internationale vergelijking al de sterkste stijging kent als het gaat om de zorguitgaven per hoofd van de bevolking gemeten in US dollars (OECD Health data, 2011). Het CBS geeft aan dat wij momenteel alles bijeen genomen zelfs al meer dan $€ 5.000$ per persoon per jaar aan zorg betalen (CBS, 2011).

Figuur 6: Uitgavenstijging per hoofd van de bevolking in US dollars (PPP)

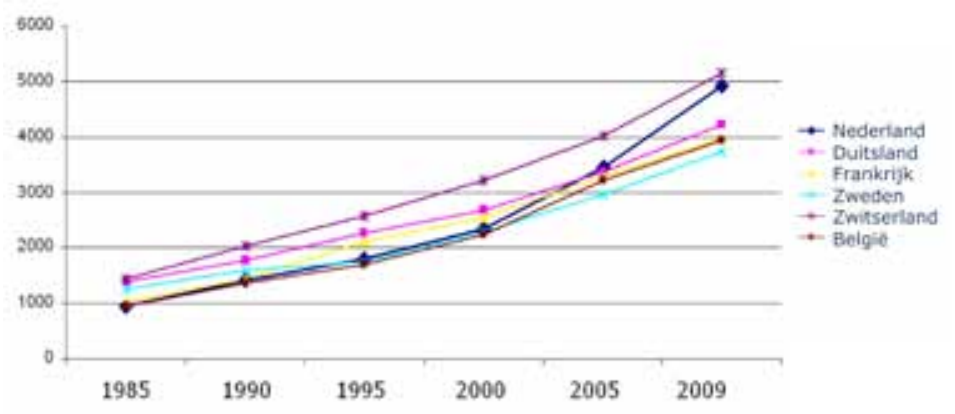

Bron: OECD Health data, 2011

Het Financieele Dagblad van 12 mei 2011 kopt met de woorden 'Duurdere zorg grootste financieel probleem'. Het artikel vormt de weerslag van een interview met de minister van Financien, Jan Kees de Jager, die zegt (opening citaat): "De schuldencrisis overleven we wel en 18 miljard bezuinigen gaat ook wel lukken, maar mijn grootste zorg is de steeds maar toenemende groei in de zorgkosten" (einde citaat). Tevens wordt er in het bericht melding 
van gemaakt dat de kosten voor zorg het afgelopen decennium met 4 procent per jaar zijn toegenomen, waar de gemiddelde economische groei 2 procent bedroeg. De reactie van De Jager is dan (opening citaat): "Dat is mathematisch onhoudbaar. Dan eet die ene categorie op een gegeven moment de hele economie op." De meest recente Volksgezondheid Toekomst Verkenning maakt ook melding van een te verwachten totale jaarlijkse groei van 4 à 5\% in de zorguitgaven ${ }^{123}$ (Van de Lucht \& Polder, 2010; Luijben \& Kommer, 2010). Dit impliceert dat wil het deel van het Bruto Binnenlands Product (BBP) dat de gezondheidszorg inneemt in de toekomst gelijk blijven, de economie jaarlijks met 4 à $5 \%$ moet stijgen. Dat is onder de huidige omstandigheden van economische recessie niet waarschijnlijk en zet de duurzaamheid van de zorg sterk onder druk.

Maar wat is het aandeel van de zorguitgaven als percentage van dat BBP? Het CPB heeft berekend dat dit aandeel in Nederland in de periode 19722010 is gestegen van zo'n 8 naar 13\%. (Van der Horst et al., 2011). Volgens de OECD volgt Nederland daarmee de VS op de tweede plaats (OECD Health data, 2011). Het CPB geeft verder aan de hand van diverse scenario's ook een toekomstbeeld van de zorguitgaven als percentage van het BBP (Van der Horst et al., 2011). Tabel 2 vat enkele gegevens samen. Het blijkt dat bij voortzetting van de historische trend de zorguitgaven in 2040 $22 \%$ van het BBP zullen uitmaken, oplopend tot zo'n 31\% als door betere zorg de levensverwachting opnieuw naar boven moet worden bijgesteld. Wat betekent dat nu voor een gezin bestaande uit tweeverdieners met een modaal inkomen voor de kostwinner en een partner met $50 \%$ van het modaalinkomen? Wordt in 2010 23,5\% van het bruto gezinsinkomen aan zorg uitgegeven, dat zal bij voortzetting van de historische trend in 2040 bijna $36 \%$ zijn of zelfs $47 \%$ bij extra toename in levensverwachting. In het laatste geval wordt de helft van het gezinsinkomen opgeslokt door zorguitgaven. Alle signalen wijzen er dus op dat er echt iets moet gebeuren en de situatie niet houdbaar is als we niets doen.

1 Op basis van demografische ontwikkelingen alleen is sprake van een volumegroei van $1,1 \%$ per jaar, die per sector geheel verschillend uitpakt. Zo bedraagt die toename voor de ouderenzorg 2,5\% maar voor de geestelijke gezondheidszorg (GGZ) en de gehandicaptenzorg minder dan 0,5\%. Extrapoleren we daar bovenop een factor 'overige volumegroei' uit het verleden (1999-2007) als gevolg van bijvoorbeeld medisch technologische ontwikkelingen, epidemiologische ontwikkelingen en beleidsintensiveringen naar de toekomst dan is een extra jaarlijkse volumegroei van $2,3 \%$ te verwachten. Daarbij opgeteld een jaarlijks te verwachten groei van $0,8 \%$ vanwege de lagere productiviteit binnen de gezondheidzorg ten opzichte van de rest van de economie (Baumo effect) resulteert dat in een totale jaarlijkse groei van ruim $4 \%$ in de zorguitgaven.

2 Wordt tevens rekening gehouden met de loon- en prijsontwikkeling, dan is de te verwachten jaarlijkse groei in de zorguitgaven circa $8 \%$.

3 Bij andere aannames kan de volumegroei voor de ouderenzorg overigens ook lager uitpakken, bijvoorbeeld door een toename van de welvaart in ons land en bij toekomstige verschuivingen in de zorg (Woittiez et. Al., 2009). Ook ziektespecifiek kan hiervan sprake zijn. 
Tabel 2: Toekomstige zorguitgaven als \% van het BBP en het gezinsinkomen

\begin{tabular}{llll}
\hline Zorguitgaven & 2010 & $\begin{array}{l}\mathbf{2 0 4 0} \\
\text { Trend }\end{array}$ & $\begin{array}{l}\mathbf{2 0 4 0} \\
\text { Meer/betere zorg }\end{array}$ \\
\hline Levensverwachting & & & \\
- mannen & 78,8 & 82,7 & 87,8 \\
- vrouwen & 82,7 & 85,7 & 89,6 \\
\% BBP & 13,2 & 22,0 & 30,8 \\
\% Gezinsinkomen (a) & 23,5 & 35,7 & 47,0 \\
\hline
\end{tabular}

(a) tweeverdiener, 11/2 modaal inkomen

Bron: Van der Horst et al., 2011

Meer zorgvraag zet de arbeidsmarkt onder grote druk en vraagt om innovaties Ten derde zal bij de toenemende vraag naar zorg en zorgverleners in de toekomst het totaal aan arbeidspotentieel in Nederland tekort schieten, ook al is het moeilijk om dat exact kwantitatief te duiden. Op basis van de demografische groeicijfers zonder 'overige volumegroei' en zonder innovatieve arbeidsbesparende vormen van zorgverlening zijn er in de periode 2007-2030 bij een gelijkblijvende deeltijdfactor 450.000 extra personen in de zorg- en welzijnssector nodig uitgaande van 1,2 miljoen mensen werkzaam in de zorg in 2007. Dit komt overeen met een jaarlijkse gemiddelde groei van 1,4\%, terwijl de beroepsbevolking daalt met $0,2 \%$. Dit resulteert in een netto tekort aan arbeidsplaatsen in de zorg van 1,6\% per jaar (Luijben \& Kommer, 2010). Uitgaande van de twee hiervoor geschetste scenario's (voortzetting historische trend versus extra toename in levensverwachting) zal in 2040 21,8 respectievelijk $28,8 \%$ van de totale werkgelegenheid worden ingenomen door personen werkzaam in de zorg tegen 12,8\% in 2010 (Van der Horst et al., 2011).

Juli 2011 berichtten diverse media op basis van een artikel van het Centraal Bureau van de Statistiek (Van den Berg et al, 2011) dat in de periode 20002010 de werkgelegenheid in de zorg spectaculair is gegroeid. Het totaal aantal banen in Nederland nam toe met 515 duizend, waarvan 385.000 in de zorg. Drie kwart van de banengroei in het afgelopen decennium is dus toe te schrijven aan de zorg, waar in 2010 reeds 1,4 miljoen mensen werkzaam waren. Indien deze trend zich voortzet zal het extra benodigde aantal personen werkzaam in de zorg van 450.000 een onderschatting zijn. 
Toename chronisch zieken vraagt om sterkere benutting preventiepotentieel Een vierde belangrijke uitdaging in het licht van de toename van het aantal ouderen en chronisch zieken ligt in het gegeven dat het preventiepotentieel sterk onderbenut is. Zoals al eerder gemeld, laat onderzoek overduidelijk zien dat voor tal van ongezonde leefstijl- of gedragsfactoren het vóórkomen in de bevolking hoog is en dat er een duidelijke relatie is tussen gedrag en gezondheid van mensen. Mackenbach zet in zijn boek 'Ziekten in Nederland' uiteen dat meer dan de helft van alle ziektegevallen in Nederland vermijdbaar is. Zoals uiteindelijk de meeste ziekten van de negentiende eeuw zijn uitgebannen, zouden ook de ziekten van nu grotendeels kunnen worden voorkómen. Wel vraagt dat om de juiste keuzes van individu en samenleving (Mackenbach, 2010).

Een kanttekening is op zijn plaats bij het noemen van deze vier maatschappelijke uitdagingen die in het bijzonder gerelateerd zijn aan ouderen en chronisch zieken. Met de invulling van mijn leerstoel zal de focus vooral daar gelegen zijn. Maar de ervaring van afgelopen jaren toen ik werkzaam was bij het ministerie van VWS hebben geleerd dat er ook grote maatschappelijke uitdagingen liggen op het terrein van infectieziekten. Het gevaar van uitbraken van nieuwe vormen van infectieziekten, de toename van infectieziekten die van dier op mens kunnen overgaan (Coutinho, 2012) alsmede de toename van antibioticaresistentie kunnen een maatschappij ontwrichten en verdienen dan ook veel aandacht. Overigens raken deze gevaren ook, en veelal in het bijzonder, juist de kwetsbare ouderen en chronisch zieken.

\section{Reacties op de maatschappelijke uitdagingen}

Ik ben dan beland bij de bovenste laag van het eerder getoonde conceptuele model waarin het beleid centraal staat. Als $u$ de media maar enigszins volgt zal u opvallen dat zowel op tv en radio als in de nationale en lokale kranten regelmatig de aandacht uitgaat naar de hiervoor genoemde maatschappelijke uitdagingen. Dit laat onverlet dat Nederland in vergelijking met andere landen hoog scoort als het gaat om de tevredenheid over de huisarts en het vertrouwen in en de toegankelijkheid van het Nederlandse zorgsysteem (Schoen et al., 2006-2011; Björnberg et al., 2009; Westert et al., 2010; IRS, 2011). De periode dat ik in de Verenigde Staten werkte, werd door de ouderenorganisatie AARP met miljoenen leden, Nederland in een internationale vergelijking met 16 geïndustrialiseerde landen uitgeroepen 
tot het beste land als het gaat om de zorg voor ouderen. We hebben er zelfs een conferentie aan gewijd. Figuur 7 laat u zien dat Nederland op een aantal kenmerken, zoals kwaliteit, toegankelijkheid en efficiëntie hoog scoort en zelfs in de totale rangorde als nummer één uit de bus komt (Appleby, 2011).

Figuur 7: Zorgprestaties in zeven landen

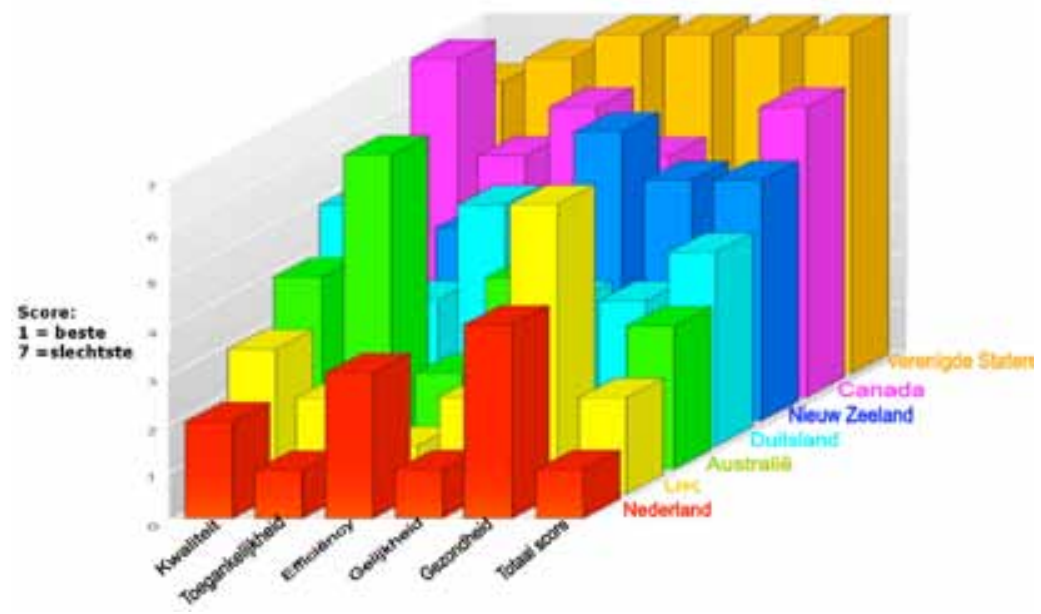

Bron: Appleby, 2011

Ook al doet Nederland het blijkbaar goed of beter dan veel andere landen, de maatschappelijke uitdagingen kunnen we daarmee niet uit de weg gaan. Dat het de politiek bezig houdt getuige ook de verschillende brieven die de afgelopen periode door minister Schippers en staatssecretaris Veldhuijzen van Zanten van VWS naar de Tweede Kamer zijn gestuurd en de daaruit voorvloeiende kamervragen en kamerdebatten (VWS, 2011a-e). Hierin zetten zij hun beleidsdoelstellingen uiteen voor deze kabinetsperiode op het terrein van preventie, welzijn, behandeling, verzorging en verpleging. Deze stukken maken ons duidelijk dat er belangrijke veranderingen en verschuivingen in de zorg gaande zijn dan wel zullen plaatsvinden om daarmee de betaalbaarheid, de toegankelijkheid en de kwaliteit te garanderen en te verbeteren. Zonder volledig te willen zijn geef ik $u$ hierbij een beeld van die veranderingen en verschuivingen. 
Positief is dat gedurende dit kabinet er 15 miljard euro extra wordt geïnvesteerd in de zorg voor het verbeteren van onder andere de scholing van medewerkers en de inzet van extra medewerkers. Maar voor uw basiszorgverzekering vallend onder de Zorgverzekeringswet (Zvw) bent $u$ per 1 januari 2012 meer gaan betalen, uw eigen risico is toegenomen van $€ 170$ naar $€_{220}$, voor bepaalde voorzieningen zijn eigen bijdragen geheven dan wel verhoogd (denk aan fysiotherapie, geestelijke gezondheidszorg) en bepaalde voorzieningen zijn uit het basispakket verwijderd (maagzuurremmers, ondersteunende geneesmiddelen bij het stoppen-met-roken programma, dieetadvies indien niet passend binnen de huidige ketendbc financiering). Ten aanzien van de Algemene Wet Bijzondere Ziektekosten (AWBZ), de verzekering voor langdurige zorg en ondersteuning, is het persoonsgebonden budget (PGB) vanaf 1 januari 2012 sterk ingeperkt en zullen voorzieningen in uitgeklede vorm verschuiven van de AWBZ naar de Zvw en van de AWBZ naar de Wmo, waarmee gemeenten meer verantwoordelijkheid krijgen. Tevens wil het kabinet vanaf 2014 in de AWBZ 'scheiden van wonen en zorg' invoeren en zal de uitvoering van de AWBZ in de toekomst niet meer gedaan worden via het zorgkantoor door de hoofdverzekeraar in een regio maar elke verzekeraar zal dit ter hand nemen voor zijn eigen verzekerdenbestand.

Enkele andere belangrijke beleidsdoelstellingen naast de verdere invoering van de marktwerking in de ziekenhuiszorg, de mondzorg en de farmacie, zijn de verschuivingen:

- van black box naar transparantie in de zorg via kwaliteitsindicatoren en de oprichting van een kwaliteitsinstituut;

- van vaste taakinvulling naar taakherschikking tussen medici en paramedici;

- van aanbod- naar vraaggestuurde zorg en meer keuzevrijheid voor de burger;

- van professionele zorg naar zelfmanagement, zelfzorg en informele zorg;

- van specialistische/intramurale zorg naar eenvoudige/extramurale zorg;

- van monodisciplinaire zorg naar multidisciplinaire ketenzorg.

Maar ook wordt ervoor gepleit dat de gezondheidszorg zich nog meer kan richten op het bevorderen van gezondheid naast het bestrijden van ongezondheid en dat zorg en preventie meer afstemming behoeven. En ook wordt een pleidooi gehouden voor intersectorale samenwerking en het aangaan van publiek-private samenwerking om burgers in staat te stellen de door de burger zelf te maken keuzes over gedrag of leefstijl aantrekkelijk 
en toegankelijk te maken. Betrokken partijen moeten dan ook werken aan een sterkere fysieke, organisatorische en inhoudelijk verbinding tussen de publieke gezondheid (zoals vastgelegd in de Wet publieke gezondheid (Wpg)) en de zorg vanuit Zvw, AWBZ en Wmo, waarbij het kabinet inzet op herkenbare en toegankelijke zorgvoorzieningen in de buurt.

En dat is precies waar ik vanuit mijn leerstoel 'Public Health and Health Care Innovation' initiërend en faciliterend wil zijn en waarvan er in Limburg en Zuid-Limburg veel beleidsinitiatieven zijn waarbij aansluiting plaatsvindt dan wel gezocht wordt (Gemeenten Zuid-Limburg, 2011; Coalitieakkoord, 2011; Gedeputeerde Staten van Limburg, 2011; Kompas voor samenwerking in Zuid-Limburg, 2011).

\section{Invulling van de leerstoel}

Maar hoe wil ik dat doen? In het begin van deze rede gaf ik aan dat de meeste burgers hun gezondheid het allerbelangrijkst vinden. Dit impliciert ook een verantwoordelijkheid van die burger voor zijn eigen gezondheid. Het naar de overheid kijken zonder de eigen mogelijkheden te benutten is dan ook geen optie. Maar die burger moet dan wel goed geïnformeerd zijn en geactiveerd worden. Vooral bij ouderen waarbij ook nogal eens sprake is van multimorbiditeit speelt zelfmanagement een grote rol. Tevens zijn er vaak meerdere zorgverleners betrokken waardoor een multidisciplinair aanpak in teamverband noodzakelijk is. Dat wordt explicieter dan in het eerder getoonde conceptuele model voor de volksgezondheid weergegeven in het Chronic Care Model dat is ontwikkeld door Wagner (Wagner et. al, 1996).

In figuur 8 vindt $u$ die geïnformeerde en geactiveerde chronische patiënt links onder in het model in interactie met een voorbereid en proactief zorgteam rechtsonder. De kernelementen vallend binnen het gezondheidszorgsysteem vindt $u$ daarboven: ondersteuning bij zelfmanagement, een focus op mutidisciplinair teamwork in het zorgproces, gebruik makend van beslissingsondersteuning in de besluitvorming in de vorm van richtlijnen en standaarden en het ter beschikking hebben van klinische informatiesystemen. Uiteindelijk gaat het om het verbeteren van het functioneren en de kwaliteit van leven van chronisch zieken via geïntegreerde zorg als respons op versnipperde huidige zorg (Kodner \& Spreeuwenberg, 2002; Gröne \& Garcia-Barbero, 2002; Stange, 2009). En dat 
we daar nog niet zijn, blijkt wel uit het boek 'Gevangen in de zorgketen' van Walter Stolz die de ziektegeschiedenis van zijn vrouw op indringende wijze beschrijft (Stolz, 2011).

Figuur 8: Het Chronic Care Model voor geïntegreerde zorg

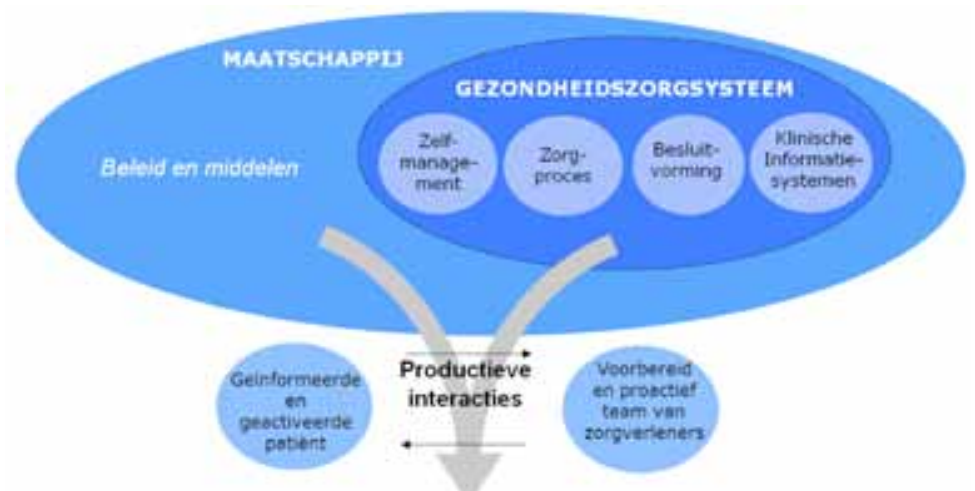

Verbeterde functionele en klinische uitkomsten

Bron: Wagner et al., 1996

Het Chronic Care Model is ontwikkeld voor toepassing in de meer klinische setting. Het is lastiger te gebruiken voor preventie en welzijn, waarbij een brede definitie van gezondheid wordt gehanteerd. Dat heeft geleid tot de ontwikkeling van het Expanded Chronic Care Model, zoals weergegeven in figuur 9 (Barr et al., 2003).

Hier speelt juist ook een geactiveerde maatschappij of gemeenschap ('community') een rol, waarbij met betrokkenheid van partners buiten de gezondheidszorg beoogd wordt de kwaliteit van leven van de chronische patiënt en de oudere maar ook van de populatie als geheel te verbeteren. De eerder genoemde kernelementen maken dan ook een verbinding tussen het zorgsysteem en de maatschappij. Maar er worden ook elementen aan toegevoegd. Dat zijn de bolletjes geheel links in het model. De toegevoegde elementen zijn dan de ontwikkeling en implementatie van gezondheidsbeleid om de gezondheid van de populatie te bevorderen, het creëren van een ondersteunende, veilige en leefbare omgeving, en het versterken, betrekken en ondersteunen van initiatieven vanuit de maatschappij of de buurt. 
Figuur 9: Het Expanded Chronic Care Model voor geïntegreerde zorg

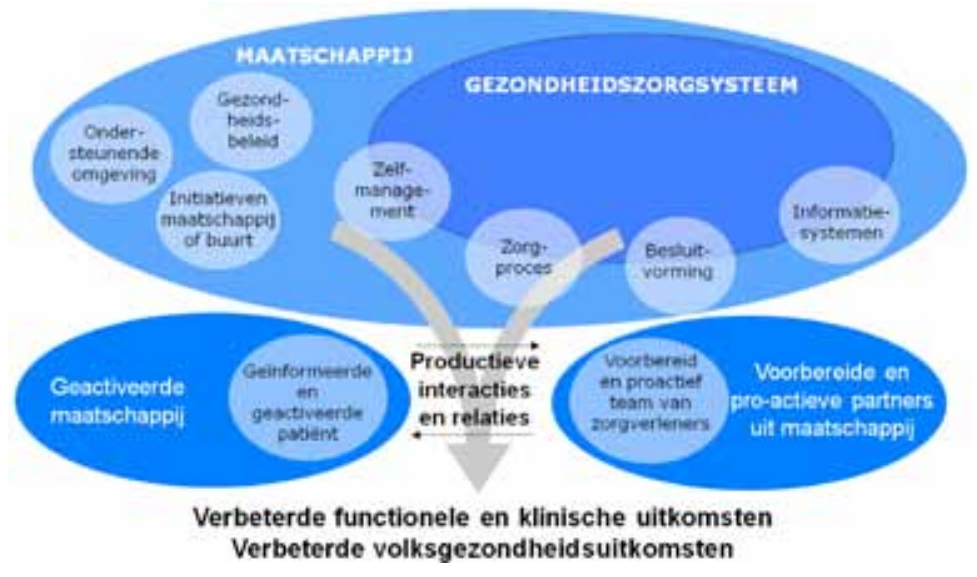

Bron: Barr et al., 2003

Het onderzoeksgedeelte behorend bij de leerstoel 'Public Health and Health Care Innovation' kenmerkt zich in het bijzonder door het integrerende en verbindende karakter waarbij het Expanded Chronic Care Model als kapstok dient. Doel is het beleid en de praktijk vanuit een brede definitie van gezondheid en vanuit het perspectief van de patiënt of burger behulpzaam te zijn bij het verder wetenschappelijk onderbouwen van een geïntegreerd aanbod van innovatieve voorzieningen. Deze moeten dan ook kwalitatief hoogwaardige en doelmatige (preventieve) zorg bieden teneinde de kwaliteit van leven en zelfredzaamheid van ouderen en mensen met chronische ziekten, dan wel degenen met een verhoogd risico daarop, te verbeteren. De gedachte hierachter is om zoveel mogelijk bij te dragen aan een noodzakelijke verschuiving van nazorg van mensen die ongezond zijn naar voorzorg om via preventie mensen gezond te houden, dus van de AWBZ en Zvw naar en de Wmo en de Wpg.

Dat is overigens geen sinecure in een zorglandschap dat zich toch vooral kenmerkt door een sterke fragmentatie in wetgeving en de daaraan gekoppelde financiering, organisatie, verantwoordelijkheden, culturen alsmede de sterk ziektespecifieke monodisciplinaire benadering. Vele actoren en processen spelen hierbij een rol en dat maakt de implemetatie en wetenschappelijke evaluatie niet eenvoudig (Baker et al., 2008; Mur- 
Veerman et al., 2008; Shih et al., 2008; Boyd et al., 2010; Rosen et al., 2011; Bousquet et al., 2011; Tinetti et al., 2011). Hier speelt ook de spanning tussen marktlogica en zorglogica, wat onder andere vragen oproept hoe concurrentie en samenwerking hand in hand kunnen gaan (Maarse, 2011) en hoe invulling gegeven wordt aan de marktwerking door zorgverleners (Porter \& Teisberg, 2006).

\section{Bijdrage van de leerstoel aan het onderzoek}

Het onderzoek kent vier hoofdlijnen:

1. De verbindingen binnen de reguliere gezondheidszorg Hier gaat het om de individuele zorg bij patiënten die zich al in het reguliere zorgcircuit bevinden. De focus ligt dan vooral op het eerst ontwikkelde Chronic Care Model dan wel beperkt zich tot het zorgsysteem van het Expanded Chronic Care Model. Feitelijk gaat het hier vooral om de verbindingen binnen de Zorgverzekeringwet maar dat kan ook tussen Zvw en de AWBZ.

Per 1 september 2011 ben ik benoemd tot programmaleider van het CAPHRI-onderzoeksprogramma Redesigning Health Care waarin het juist gaat om vanuit nieuwe zorgconcepten verbindingen binnen en tussen zorginstellingen en zorgverleners te leggen met een sterke interactie tussen praktijk, beleid en onderzoek. Er zijn nieuwe initiatieven gaande op het terrein van interne geneeskunde, cardiologie en KNO. De komende periode zal verder verkend worden waarop nader onderzoek ingezet zal worden om vanuit het perspectief van de patiënt de zorg in Zuid-Limburg zoals geleverd door zorggroepen in de eerste lijn en door het ziekenhuis in de tweede lijn meer met elkaar te verbinden. Tevens hoop ik vanuit mijn rol als voorzitter van de landelijke stuurgroep Zichtbare Zorg op het terrein van de chronische zorg en de landelijke stuurgroep Zichtbare Zorg op het terrein van huisartsenzorg bij te mogen dragen aan de integratie en tranparantie van de verleende zorg. Mijns inziens moeten we af van de sterke tweedeling tussen de eerste lijn, waaronder de huisartsenzorg, en tweede lijn, waar de ziekenhuiszorg onder valt. Interessant vind ik in dit verband of de integrale bekostiging van diabetes, die zich nu beperkt tot de eerste lijn en consulten vanuit de tweede lijn, niet verbreed moet worden naar poliklinische en klinische zorg. Ook vind ik het interessant om vanuit het patiëntenperspectief te verkennen wat de mogelijkheden zijn om de ziekenhuiszorg anders vorm te gaan geven en toe te werken naar 'senior-friendly hospitals' (KNMG, 2010; RGP, 2012) en het verkennen van de mogelijkheden van 
het terugdringen van polyfarmacie bij ouderen door jaarlijkse checkups. Rode draad is dat de toenemende multimorbiditeit veel meer een holistische dan een ziektespecifieke of orgaanspecifieke benadering vraagt.

Het belang van het verder ontwikkelen van geïntegreerde zorg wordt benadrukt door vele landen, waaronder Nederland (Van der Linden et al., 2001; Van Raak et al., 2003; Leichsenring \& Alaszewski, 2004; Kümpers, 2005; Berwick et al., 2008; Rosendal et al., 2009, Gress et al., 2009; Curry \& Ham, 2010; Vrijhoef, 2010; KNMG, 2010; NPCF, 2012). In Nederland geven we daar onder andere invulling aan via ziektespecifieke zorgstandaarden die we inmiddels kennen voor onder andere diabetes mellitus (NDF, 2007). Maar die invulling is nog erg ziektespecifiek en de uitdaging is hoe om te gaan met multimorbiditeit (Coördinatieplatform Zorgstandaarden, 2011; NDF, 2011). Het Maastricht UMC+ pleit ook voor meer integrale zorg op het brede continuüm van preventie, basiszorg en topklinische diagnostiek en behandeling en geeft aan dat de aandacht zich moet verbreden van ziekte naar het totale continuüm van gezondheid en ziekte (Maastricht UMC+, 2010). Het is ook een speerpunt van het beleid. Hierbij is het academisch ziekenhuis Maastricht een schakel in een zorgketen. Het Maastricht UMC+ heeft ook een lange historie en is landelijk gezien een voorloper in innovaties op het terrein van geïntegreerde zorg (Vierhout et al, 1995; Vrijhoef \& Fiolet, 2011). Dit sluit ook naadloos aan op de ambities die ik heb bij de invulling van mijn leerstoel.

2. De verbindingen tussen de reguliere en openbare gezondheidszorg In de tweede onderzoekslijn staat centraal de verbinding tussen enerzijds de individuele zorg aan patiënten met een gezondheidsprobleem, zoals $u$ gewend bent in de reguliere zorg, en anderzijds de publieke gezondheidzorg en daarmee de collectieve preventie, waarbij het veeleer gaat om de bevolking dan wel groepen daaruit met een verhoogd risico op ongezondheid. Feitelijk gaat het hier om de verbinding tussen de Zvw en de Wpg. De focus van deze onderzoekslijn binnen het Expanded Chronic Care Model ligt dan veeleer richting de maatschappij. Groot probleem is echter dat uitgaande van de huidige schotten in wetgeving en financiering de verbinding tussen de individuele zorg en de publieke gezondheidszorg op landelijk niveau niet of moeizaam tot stand komt. Ik ben er dan ook sterk voorstander van om, als het binnen het kader van de huidige wetgeving moet plaatsvinden, veeleer de regionale mogelijkheden te verkennen en benutten. Laat ik u een voorbeeld geven. 
Onlangs is het PreventieConsult Cardiometabool Risico ontwikkeld (Dekker, 2011). Het doel hiervan is het voorkómen van hart-en vaatziekten, diabetes mellitus type 2 en chronische nierschade door opsporing van degenen met een verhoogd risico hierop. Het gaat hier dus expliciet om risicopersonen in de bevolking op te sporen en indien nodig te behandelen waardoor een verbinding gelegd wordt tussen de selectieve en daarmee collectieve preventie waar van oudsher de openbare gezondheidszorg, waaronder de GGD, een belangrijke rol speelt, gekoppeld aan (indien geïndiceerd) bijpassende leefstijladviezen of medicamenteuze therapie, veeleer ingebed in het reguliere eerstelijnszorgsysteem. Gefinancierd door de Nederlandse Hartstichting, de Nierstichting en het Diabetes Fonds binnen het programma 'LekkerLangLeven' zijn wij in samenwerking met Tranzo van de Universiteit Tilburg, de GGD ZuidLimburg/Academische Werkplaats Publieke Gezondheid Limburg en het RIVM gestart met een verkenning naar de regionale implementatieen financieringsmogelijkheden van het preventieconsult. Dit mede omdat het actief opsporen van risicogroepen alsmede bepaalde vormen van preventieve zorg bij hoogrisicopersonen niet vallen onder het basispakket (Latta, 2011). Parallel daaraan is in samenwerking met het RIVM en in afstemming met het NIVEL gestart met een ex-ante kosteneffectiviteitsanalyse om te onderzoeken of de extra kosten van zo'n preventieconsult opwegen tegen de (maatschappelijke) baten.

3. De verbindingen tussen de gezondheidszorg, zowel regulier als openbaar, met andere sectoren

Omdat gezondheid meer is dan de afwezigheid van ziekte en de inspanningen bij de reguliere en openbare gezondheidszorg toch vooral betrekking hebben op het behandelen dan wel voorkómen van ziekten, zijn er meer actoren in het spel die kunnen bijdragen aan een goede gezondheid. Eerder publiceerde de Raad voor de Volksgezondheid en Zorg al dat er een accentverschuiving moet plaatsvinden van 'Zorg voor Ziekte' naar 'Gedrag en Gezondheid' met een duidelijke verantwoordelijkheid voor de burger zelf, ook wel de verschuiving van ZZ naar GG genoemd (RVZ, 2010a, RVZ, 2010b). Ik steun dat van harte. Ik vind in algemene zin dat we in de gezondheidszorg nog veel teveel gefocust zijn op het genezen van ziekten in plaats van de aandacht te vestigen op gezondheid en de (rest)capaciteit van mensen om daadwerkelijk te participeren in de maatschappij. Dat raakt terreinen als betaald en vrijwilligerswerk, maar ook een oriëntatie op wonen en welzijn. We spreken dan ook wel van een verschuiving in aandacht van pathogenese naar salutogenese 
(Antonovsky, 1996; Lezwijn et al., 2011). Nadrukkelijk dienen we daarmee ook de gemeenten te betrekken nu zij een grotere verantwoordelijkheid krijgen bij meer taken die onder de Wmo gebracht gaan worden. De verschuiving die de Raad voor de Volksgezondheid en Zorg aangeeft, dient mijns inziens nog verder te gaan: van ZZ en GG naar MM, waarvoor MM staat voor 'Meedoen in de Maatschappij'. Intersectorale samenwerking richting welzijn, wonen en ruimtelijke ordening speelt hier een belangrijke rol. Het belang van de focusverbreding van zorg naar wonen en welzijn wordt onderstreept in de recent gepuliceerde visie van de Koepel van Ouderenorganisaties CSO, de Nederlandse Federatie van Universitair Medische Centra en ZonMw over de toekomstige ouderenzorg (CSO et al., 2012). Binnen het Expanded Chronic Care Model ligt de focus dan vooral op de maatschappij ('community'), hetgeen internationaal nog een sterk onontgonnen terrein is.

Als onderdeel van een veelomvattend onderzoeksproject getiteld 'Integrated Senior Services,' dat wordt gefinancierd door ZonMw vanuit het Nationaal Programma Ouderenzorg, wordt momenteel in samenwerking met de GGD Zuid-Limburg/Academische Werkplaats Publieke Gezondheid Limburg onderzoek gedaan in de regio Parkstad waar vergrijzing nu al samengaat met aanzienlijke krimp van de bevolking en waar leefbaarheid, sociale cohesie en arbeidsmarkt onder druk staan. Doel is het optimaliseren van het functioneren en de kwaliteit van leven van ouderen door het realiseren van een samenhangend, sluitend en voor de burger op maat toegesneden ondersteuningsaanbod waarin partners op het terrein van preventie, zorg, welzijn, wonen en financiering op een innovatieve manier samenwerken. Uiteindelijk gaat het om het creëren van een levensloopbestendige buurt. Een korte anecdote van wat verstaan kan worden onder 'een voor de burger op maat toegesneden ondersteuningsaanbod'. Een aantal maanden geleden vroeg mijn 85-jarige moeder mij advies of ze nu gebruik moest maken van huishoudelijke hulp. Zij was er op aangesproken dat zij er recht op had. Ik heb haar negatief geadviseerd omdat ze zich prima zelf kan verzorgen en juist daardoor ook fit blijft. We moeten af van het idee ergens recht op te hebben omdat het aangeboden wordt. We moeten veeleer uitgaan van waar echt behoefte aan is, zodat de zorg daar landt waar het het meest nodig is. 


\section{Convergentie drie onderzoekslijnen}

De drie onderzoekslijnen staan niet op zich. Zij hangen nauw samen en hopen een wetenschappelijk gefundeerde bijdrage te leveren aan de noodzaak om gezondheids- en welzijnszorg anders vorm te geven. Het Expanded Chronic Care Model in zijn volle omvang staat dan centraal. De sterke fragmentatie in wetgeving en de daaraan gekoppelde financiering, organisatie, verantwoordelijkheden, culturen alsmede de sterk ziektespecifieke monodisciplinaire benadering is niet toekomstbestendig. We moeten af van de huidige obstakels en perverse prikkels die belemmerend werken om via proeftuinen innovatie in de zorg een kans te geven en juist prikkels creëren om preventie te stimuleren (Schlette, 2009). Dat vraagt wel om visie en durf.

Door de bekostiging van de zorg vanuit de Zvw, AWBZ, Wmo en Wpg regionaal te bundelen en de hoogte ervan te baseren op regionale populatiekenmerken over (on)gezondheid, zorgbehoefte en zorggebruik, kunnen financiële obstakels en daarmee negatieve prikkels voor kostenbesparingen geslecht worden. Er dient naar gestreefd te worden om zoveel mogelijk vanuit het perspectief van de burger te sturen op gezondheidsuitkomsten, of op zorgprocessen die voorspellend zijn voor gezondheidsuitkomsten, in plaats van zorgproductie. Maar ook op het mijden van dure intramurale zorg door sterker in te zetten op de voorkant van het zorg- en welzijnscontinuüm ('van nazorg naar voorzorg'). De versterkte en goedkopere inzet aan de voorkant dient de duurdere en minder benodigde zorg aan de achterkant te compenseren waardoor besparingen geboekt kunnen worden waarvan een deel als 'shared savings' naar de burger terugvloeit om de premiestijging te reduceren. Maar ook naar de besparende organisatie en verzekeraar voor nieuwe zorginnovaties die bijvoorbeeld in samenwerking met het bedrijfsleven bijdragen aan een verdere kostenbesparende en kwaliteitsverbeterende zorg.

Optima forma zou de proeftuin de volgende elementen kunnen bevatten:

- regionale afspraken tussen financiers (verzekeraar en overheid op lokaal, provinciaal, en nationaal niveau);

- gebaseerd op de regionale populatiekenmerken over (on)gezondheid, zorgbehoefte en zorggebruik mede op basis van het koppelen van (bestaande) informatiesystemen;

- waarbij financiële obstakels geslecht worden (ZVW, AWBZ, WMO, Wet PG);

- en doelen worden gesteld (micro-, meso- en macroniveau); 
- met incentives voor de zorgverleners, burgers en het bedrijfsleven;

- met maximale betrokkenheid van de client, burger of patiënt;

- en uitdagingen voor het onderzoek, en de valorisatie daarvan, en het onderwijs;

- ten behoeve van een duurzaam, betaalbaar en kwalitatief goed zorgstelsel;

- ten einde bij te dragen aan betrokkenheid bij de zorg en de gezondheid van de bewoners in die regio en langs die weg aan de economische groei.

De relatief slechte gezondheidssituatie en de hogere blootstelling aan risicofactoren in Zuid-Limburg, gecombineerd met een snelle vergrijzing en ontgroening, als mede de dominantie van twee zorgverzekeraars en een overzichtelijk aantal zorgaanbieders maakt dat Zuid-Limburg de perfecte regio zou zijn voor een dergelijke proeftuin. Onder andere in Duitsland zijn hiermee de eerste ervaringen opgedaan (Hildebrandt et al., 2010; McClellan, et al., 2010) en voor de regio Zuid-Limburg vinden momenteel gesprekken plaats op bestuurlijk niveau om dit verder te verkennen (Kompas voor samenwerking, 2011). Ook de Provinciale Raad voor de Volksgezondheid Limburg heeft hierover onlangs advies uitbebracht op het terrein van de ouderenzorg (PRV Limburg, 2011). De bewindspersonen van VWS geven per brief aan de Tweede Kamer aan ruimte te zullen geven aan dergelijke innovaties (VWS, 2011e). Ook wil het kabinet proeftuinen stimuleren voor het testen en demonstreren van innovaties (EL\&l, 2011).

Maar de vraag is of de tijd rijp is voor zo'n proeftuin 'optima forma'. Eerste stappen zouden gezet kunnen worden door bijvoorbeeld binnen het kader van de Zvw de zorguitgaven voor chronisch zieken in de eerstelijn en het ziekenhuis integraal te bekostigen. Mijns inziens is het koudwatervrees als gedacht wordt dat de ziekenhuiszorg uitgekleed wordt door een verschuiving naar de eerstelijn te bewerkstelligen. Het gaat veeleer om het beteugelen van de verdere groei in het ziekenhuis omdat de vergrijzing in toenemende mate zal blijven drukken op de ziekenhuiszorg. Een andere mogelijkheid is om de zorguitgaven voor ouderen en chronisch zieken vanuit de Wpg, de Wmo en de AWBZ integraal te bekostigen. Waarom zullen gemeenten investeren in preventie via de Wpg en investeren in begeleiding van chronisch zieken en ouderen via de Wmo als de revenuen door besparingen in de AWBZ niet terugvloeien naar de gemeenten? Dan kan het financieel veel aantrekkelijker zijn om ouderen niet zolang mogelijk via ondersteuning 
thuis te laten wonen maar te laten opnemen in een verpleeghuis. De financiële schotten moeten weg of op zijn minst moeten er deuren tussen schotten geopend worden.

De effecten van dergelijke proeftuinen dienen nauwgezet wetenschappelijk gevolgd en geëvalueerd te worden. Resultaten uit de proeftuinen kunnen regionaal, nationaal en zelfs internationaal worden uitgedragen. Vanuit mijn leerstoel en vanuit onze vakgroep Health Services Research, gekenmerkt door een sterk multidisciplinair gezelschap met medische, paramedische, bestuurlijke, organisatorische en gezondheidseconomische expertise, zijn wijgraag bereid om via de drie door onze vakgroep geleide onderzoeksprogramma's 'Redesigning Health Care', 'Innovations in Health Care for the Elderly' en 'Health Technology Assessment' in samenwerking met andere onderzoeksprogramma's en instituten hier ondersteuning aan te bieden en de resultaten te benchmarken met ontwikkelingen elders in Nederland en internationaal. Geïntegreerde zorg vraagt als onderbouwing ook geïntegreerd onderzoek en dat kunnen wij bieden.

In dergelijke proeftuinen gaan praktijk, beleid, bedrijvigheid en onderzoek hand in hand en juist hier dient het onderzoek niet alleen op zijn wetenschappelijke maar ook op zijn maatschappelijke impact gewaardeerd te worden (Jansen \& Ruwaard, 2012). Dit past ook uitstekend binnen de missie van de CAPHRI School for Public Health and Primary Care waar de leerstoel en de vakgroep onderdeel van uitmaken en die onlangs via een officiële externe evaluatie de hoogst mogelijke score kreeg als het gaat om de kwaliteit en maatschappelijke relevantie van het door de school geleverde onderzoek en onderwijs (ERC, 2011). Tevens sluit dat ook prima aan bij de ontwikkeling van de Maastricht Health Campus (http://www.maastrichthealthcampus.nl/) en Brainport 2020 (http://www.brainport2020.nl).

Een interessant model voor de toekomst vind ik om vanuit een regionaal bekostigingsmodel wijkgerichte gezondheids- en welzijnscentra de centrale uitvoeringsorganisatie te laten zijn. Hierin dienen de huidige eerstelijnsfuncties inclusief de wijkverpleging, de consultatiefuncties van de tweedelijn alsmede de preventieve functies van de openbare gezondheidszorg (GGD) en de welzijnsfunctie van de gemeenten gecombineerd te worden aangeboden. Alleen voor echt complexe danwel langdurige problematiek hebben we intramurale instellingen zoals ziekenhuizen en verpleeghuizen ter beschikking. 
Ik hecht er nadrukkelijk aan de kostenontwikkelingen in de zorg voor u nog in een breder en positiever perspectief te plaatsen. We staan voor grote uitdagingen maar het is niet alleen kommer en kwel. Een verschuiving van nazorg naar voorzorg impliceert een betere gezondheid hetgeen van groot belang is voor ons als persoon, maar het draagt ook bij aan de economie en daarbij aan de welvaart van een land (Fogel, 2004; Pomp, 2010, Post NAM et al, 2010). Hiervoor kan ook wel de Engelstalige uitdrukking 'Health is wealth' gebruikt worden. Gezondheid beïnvloedt de schoolprestaties positief en kan een rol spelen bij de vermindering van de kosten als gevolg van ziekteverzuim en arbeidsongeschiktheid en stelt ons in staat langer te blijven werken en is ook een belangrijke voorwaarde voor vrijwilligerswerk en mantelzorg en deelname aan het maatschappelijke leven. Tevens hebben we die gezonde bevolking ook nodig om het dreigend arbeidstekort in de zorg op te vangen. Hiermee snijdt het mes aan twee kanten. Betere preventie en zorg leiden tot een gezondere bevolking en het extra arbeidspotentieel (formeel en informeel) kan weer ingezet worden om de gezondheid van de bevolking op peil te houden. Ik kan mij dan ook behoorlijk ergeren aan uitspraken, ook vanuit de Tweede Kamer, dat preventie slechts extra zorgkosten genereert omdat deze mensen ook ouder worden. Hierbij worden de maatschappelijke baten van een goede gezondheid totaal genegeerd. Ook hier blijkt dat we gevangen zitten in hokjesdenken en de kosten en baten niet als communicerende vaten zien. Als we zo redeneren dan moet je een patiënt met een acute blinde darmonsteking ook niet behandelen want een dode patiënt blijft de goedkoopste patiënt.

\section{Bijdrage van de leerstoel aan het onderwijs}

Dat wat betreft de bijdrage aan het onderzoek. Ten aanzien van het onderwijs zal de leerstoel 'Public Health and Health Care Innovation' bijdragen leveren aan de verschillende curricula binnen de bachelor en master gezondheidswetenschappen en geneeskunde van de Faculty of Health, Medicine and Life Sciences van het Maastricht UMC+ als ook het University College Maastricht. Het onderwijs zal een duidelijk gezicht geven op innovatief Health Services Research gerichte modules/leergangen om daarmee jong en aankomend toptalent aan ons te binden voor het onderzoek dan wel klaar te stomen voor andere posities. Zo wordt vanuit de leerstoel een bijdrage geleverd aan de master Health Policy, Innovation and Management, waarbij afstudeerders worden opgeleid voor posities bij overheden, onafhankelijke bestuurs- en adviesorganen, zorginstellingen, adviesbureaus, zorgverzekeraars, WHO, EU, onderzoeksinstituten, universiteiten en HBO's. De leerstoel richt zich sterk op de vertaling van 
beleid en praktijk naar onderzoek en onderwijs en vice versa. Het onderwijs is waar mogelijk dan ook sterk praktijkgericht en interactief vormgegeven. Vanuit mijn leerstoel wil ik ook graag bijdragen aan innovaties op het terrein van onderwijs om juist ook vanuit de drie studierichtingen binnen de faculteit, te weten geneeskunde, gezondheidswetenschappen en biomedische wetenschappen, het integrale onderwijs vanuit het concept van geïntegreerde zorg meer vorm te geven. Een andere zorg vereist immers ook andere professionals. Maar ook draag ik graag bij aan ontwikkelingen voor het opzetten van het postacademisch onderwijs en alumnionderwijs.

\section{De weg van nazorg naar voorzorg: buiten de gebaande paden}

De titel van deze oratie luidt niet voor niets 'De weg van nazorg naar voorzorg: buiten de gebaande paden'. Zoveel als mogelijk is het doel om vanuit het onderzoek en het onderwijs bij te dragen aan een noodzakelijke verschuiving waarbij zolang mogelijk zo min mogelijk zorg nodig is; een verschuiving van nazorg naar voorzorg. Laat ik het krachtiger formuleren. Ons zorgstelsel moet op de schop. De bestaande schotten in de financiering belemmeren het streven naar een duurzaam, betaalbaar en kwalitatief goed zorgstelsel. Innovaties zijn dan ook nodig waarin ruimte moet zijn om buiten de gebaande paden wegen te vinden om hier invulling aan te geven. Ik hoop van harte dat mijn kennis en ervaring die niet alleen vorm hebben gekregen binnen (onder andere: Steering Committee on Future Health Secnarios 1991, 1993, 1994; Ruwaard et al, 1993, 1994, 1996a, 1996b; 1997, 2000; Postma et al,. 1995; Hirasing et al., 1996; Baan et al., 1998, 1999; Berg Jeths et al., 2000; Gijsen et al., 2001; Spijkerman et al., 2003, 2004; Van Houtum et al, 2004), maar ook buiten de wetenschappelijke paden een bijdrage kunnen leveren om te zoeken naar wegen om uiteindelijk de chronisch zieken en ouderen in onze bevolking van dienst te zijn. 


\section{Dankwoord}

Ik ben bijna aan het einde van mijn rede gekomen en daarbij past een woord van dank. Ik zou hier niet staan zonder de steun van velen. Allereerst wil ik het College van Bestuur van de Universiteit Maastricht, waaronder rector Gerard Mols, het bestuur van de Faculty of Health, Medicine and Life Sciences, waaronder oud-decaan Martin Paul en oud vice-decaan Frits van Merode, alsmede de directeur van de CAPHRI School for Public Health and Primary Care, Onno van Schayck, en de directeur van het Onderwijsinstituut Gezondheidswetenschappen, Rob de Bie, danken voor het in mij gestelde vertrouwen. Dit wil ik des te meer omdat ik niet uit het Maastrichtse kom en mijn loopbaan zich breder uitstrekte dan de wetenschap alleen. Ik zal mij met veel plezier inzetten om jullie vertrouwen niet te beschamen.

Mijn bijzondere dank gaat uit naar de oud-voorzitters van de vakgroep Verpleging en Verzorging, Jan Hamers en Ruud Kempen, en de oud-voorzitter van de vakgroep Beleid, Economie en Organisatie van de Zorg, Hans Maarse, alsmede Arno van Raak van diezelfde vakgroep. Jullie boden de gelegenheid om alvorens ik definitief instemde, heel open en vertrouwelijk te verkennen wat de meerwaarde zou kunnen zijn van de nieuwe vakgroep, of het fusietraject een kans van slagen zou hebben en of er voldoende onderling vertrouwen en respect zou zijn. Dat heeft mij veel goed gedaan en jullie hebben mij overtuigd om de stap naar het zuiden te zetten. Bij mijn start is direct het fusietraject in gang gezet en binnen een half jaar afgerond. Ik wil bij deze alle medewerkers van de nieuwe vakgroep veel dank zeggen voor het in mij gestelde vertrouwen als nieuwe vakgroepvoorzitter alsmede voor de constructieve opstelling tijdens de reorganisatie, zelfs als het gaat om de keuze van een nieuwe naam van de vakgroep. We zetten er gezamenlijk de schouders onder om deze vakgroep nationaal en internationaal op zowel onderzoeks- als onderwijsgebied met een sterke maatschappelijke oriëntatie zowel wetenschappelijk als maatschappelijk in de frontlinie te laten opereren. Een woord van dank is ook op zijn plaats aan André Knottnerus, Cor Spreeuwenberg en Bert Vrijhoef. Op de achtergrond speelden zij ook een belangrijke rol om mij alle vertrouwen en steun te geven om zo'n stap te zetten.

Buiten Maastricht zijn er gedurende mijn loopbaan velen geweest die mij hebben gevormd en daarmee indirect ook hebben bijgedragen aan de positie die ik nu bekleed hier in Maastricht. Natuurlijk vindt er al veel vorming plaats gedurende je opleiding als arts en gedurende mijn specialisatie als arts 
Maatschappij en Gezondheid. Maar juist mijn verschillende werkplekken hebben mij verder verrijkt in kennis en ervaring. Ik ben Daan Kromhout en Harry Verkleij veel dank verschuldigd voor het in mij gestelde vertrouwen te starten met onderzoek op het terrein van chronische ziekten bij de Medische Faculteit van de Rijksuniversiteit Leiden. We zijn jaren nauw met elkaar opgetrokken en er waren steeds weinig woorden nodig om elkaar te begrijpen. Dat bleek al tijdens het sollicitatiegesprek in 1988. Het klikte en voelde direct goed. Gezamenlijk zijn we naar het RIVM vertrokken en heb ik de gelegenheid gekregen om door te groeien van onderzoeker naar hoofd van het Centrum voor Volksgezondheid Toekomst Verkenningen en uiteindelijk naar directeur van de sector Volksgezondheid. Ik ben behalve Daan Kromhout ook Pieter Kramers en Gijs Elzinga veel dank verschuldigd om die doorgroei te mogen maken. Ik heb de gelegenheid gehad om met velen zowel binnen als buiten het RIVM op zeer constructieve wijze samen te werken en ik kijk daar nog steeds met erg veel plezier naar terug. Ook wil ik Daan Kromhout en Ton Casparie als promotoren en Harry Verkleij als co-promotor dank zeggen voor hun steun bij mijn promotie-onderzoek dat naast het gewone werk heeft plaats gevonden.

De stap om als gezin drie jaar te verblijven in de Verenigde Staten om aldaar en in Canada over de volle breedte van het werk van het ministerie van VWS, datzelfde ministerie daar te mogen vertegenwoordigen was gewaagd maar pakte zeer goed uit. Het stelde mij in de gelegenheid om mijn kennis verder te verruimen vanuit de public health naar de cure, care en welzijn en ervaring op te doen op het terrein van de internationale verhoudingen en diplomatie. Ik zeg wel eens tegen collega's dat ik het ministerie beter heb leren kennen op $6.000 \mathrm{~km}$ van Den Haag dan tijdens mijn werk op het RIVM in Bilthoven op slechts luttele afstand van Den Haag.

Maar om het beleidswerk echt te leren kennen is het noodzakelijk om met beide benen midden in de dagelijkse Haagse hectiek te staan. De viereneenhalf jaar voorafgaande aan mijn aanstelling in Maastricht heb ik het voorrecht gehad directeur van de directie Publieke Gezondheid van het ministerie van VWS te mogen zijn. Ik wil Hans de Goeij en Paul Huijts als directe bazen maar ook Ab Klink als oud-minister en alle collega's van de directie en anderen binnen het ministerie van harte dank zeggen voor de mooie periode. Er wordt door buitenstaanders nog wel eens minachtend neergekeken op ambtenaren in het Haagse. Ik zou zeggen, waag de stap en pak de handschoen op als je de gelegenheid krijgt. Het is dynamisch, hectisch en hard werken tezamen met zeer betrokken collega's. 
Tenslotte is er ook nog een privéleven en de mensen waar het uiteindelijk om gaat. Moeder, ik ben zeer blij dat $u$ op de leeftijd van 85 jaar hier getuige van mag zijn. Ik weet dat $u$ trots bent op wat ik doe ook al valt het niet mee om duidelijk te maken wat ik nu precies doe. Ik hoop dat deze rede nog wat meer helderheid heeft gegeven. Eigenlijk doet dat er ook niet toe. Ook al woont $u$ nog zelfstandig en doet $u$ veel zelf ben ik zeer blij dat mijn zus Janneke die dicht bij u woont altijd direct voor $\mathrm{u}$ klaar staat als er iets is, maar ook als er niets is. Janneke, veel dank. Helaas is vader te vroeg overleden en heeft hij veel van de mooie momenten in onze familie niet mogen meemaken. Dat geldt ook al sinds een aantal jaren voor mijn schoonouders. Zij zouden trots zijn geweest.

Helina, zonder jou had dit alles natuurlijk nooit mogelijk geweest. Je hebt mij altijd ten volle gesteund in de stappen die ik tijdens mijn loopbaan heb mogen zetten, of het nu mijn eerste stap op de arbeidsmarkt, ons verblijf als gezin in Amerika of deze laatste stap naar het zuiden betrof. Je corrigeert mij ook als ik de balans weer eens kwijt ben tussen werk en privé. We zijn inmiddels bijna 32 jaar een hecht stel. Ik hoop dat we nog vele jaren in goede gezondheid van elkaar mogen genieten. En wat zijn we blij met onze kinderen Suzanne, Corné en Lotte en sinds drie jaar ook Freek. We zien jullie opgroeien tot welbewuste, betrokken en toegewijde jonge mensen waarbij wij vol trots de toekomst tegemoet zien en ons gezegend voelen jullie ouders en toekomstige schoonouders te mogen zijn.

Ik heb gezegd. 


\section{Referenties}

Antonovsky A. The salutogenic model as a theory to guide health promotion. Health Promotion Int 1996; 11: 11-18.

Appleby J. Which is the best health system in the world? BMJ 201: 343: d6267.

Baan CA, Bonneux L, Ruwaard D, Feskens EJM. The prevalence of diabetes mellitus in the Netherlands: a quantitative review. European Journal of Public Health 1998; 8: $210-216$.

Baan CA, Nusselder WJ, Barendregt JJ, Ruwaard D, Bonneux L, Feskens EJM. The burden of mortality of diabetes mellitus in the Netherlands. Epidemiol 1999; 10: 184-187.

Baker GR, MacIntosh-Murray A, Porcellato C, Dionne L, Stelmacovich K, Born K. High performing healthcare systems: delivering quality by design. Toronto: Longwood Publishing, 2008.

Barr VJ, Robinson S, Marin-Link B, et al. The Expanded Chronic Care Model: an integration of concepts and strategies from population health promotion and the chronic care model. Hospital Quarterly 2003; 7: 73-82.

Berg H. van den, Tsang-Ason S, Zwan J van der. Werkgelegenheid zorg groeit spectaculair. Voorburg: Centraal Bureau voor de Statistiek, 2011.

(http://www.cbs.nl/nl-NL/menu/themas/arbeid-sociale-zekerheid/publicaties/artikelen/archief/2011/2011-3440-wm.htmCBS)

Berg Jeths A van den, Ruwaard D, Verkleij H. De invloed van demografische en epidemiologische ontwikkelingen op het aantal chronisch zieken in de toekomst. Tijdschrift voor Gezondheidswetenschappen 2000; 78: 75-80.

Berwick DM, Nolan TW, Whittington J. The Triple Aim: care, health, and cost. Health Affairs 2008; 27: 759-769.

Björnberg A, Garrofé BC, Lindblad S. Euro Health Consumer Index 2009. Sweden, Danderyd: Health Consumer Powerhouse, 2009

Blokstra A, Verschuren WMM (red.). Vergrijzing en toekomstige ziektelast. Prognose chronische ziektenprevalentie 2005-2025. Rapnr 260401/2007. Bilthoven: Rijksinstituut voor Volksgezondheid en Milieu, 2007.

Bousquet J, Anto JM, Sterk PJ, et al. Systems medicine and integrated care to combat chronic noncommunicable diseases. Genome Medicine 2011; 3 (http:// genomemedicine.com/content/3/7/43) 
Boyd CM, Fortin M. Future of multimorbidity research: how should understanding of multimorbidity inform health system design? Public Health Reviews 2010; 32: 451-474.

Brink-Muinen A van den, Rijken PM, Spreeuwenberg P, Heijmans MWJM. Kerngegevens Maatschappelijke situatie 2008. Nationaal Panel Chronisch zieken en Gehandicapten. Utrecht: NIVEL, 2009.

Bruggink JW (CBS), Knoops K (CBS), Nusselder WJ (ErasmusMC), Gool CH van (RIVM). De gezonde levensverwachting samengevat. In: Volksgezondheid Toekomst Verkenning, Nationaal Kompas Volksgezondheid. Bilthoven: RIVM, <http://www.

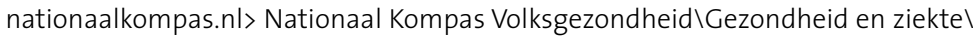

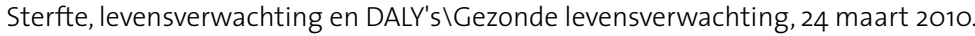
Nationaal Kompas Volksgezondheid, versie 4.6,15 december 2011.

CBS. Centraal Bureau voor de Statistiek. Zorgrekeningen. StatLine, 2011.

(http://statline.cbs.nl/StatWeb/publication/?VW $=T \& D M=S L N L \& P A=71914 N E D$ $\& D 1=0-23,37-45 \& D 2=9-I \& H D=101210-0925 \& H D R=G 1 \& S T B=T$; geraadpleegd op 21 maart 2012)

Coalitieakkoord 2011-2015. Meer Limburg, minder overheid. PVV-CDA-VVD. Maastricht: Provincie Limburg, 2011.

Coetinho RA. Van dier naar mens. Zoönosen in een wereld in verandering. Inaugurele rede. Utrecht, 10 februari 2012. (http://www.uu.nl/NL/Actueel/Pages/ OratieRoelCoutinho.aspx; geraadpleegd op 17 maart 2012)

Coördinatieplatform Zorgstandaarden. Werkpogramma 2012. Den Haag: ZonMw, 2011. http://www.zorgstandaarden.nl/het-cooerdinatieplatform-zorgstandaarden/; geraadpleegd op 17 maart 2012)

CSO, NFU, ZonMw. Toekomstige ouderenzorg; kernwaarden, opbrengsten en perspectief. De visie van CSO, NFU en ZonMw, 2012. (http://www.nationaalprogrammaouderenzorg.nl/fileadmin/www.npoz.nl/documenten/brieven/visieouderenzorg-jan2012.pdf; geraadpleegd op 17 maart 2012)

Curry N, Ham C. Clinical and service integration. The route to improved outcomes. London: King's Fund, 2010.

Dekker JM, Alssema M, Janssen PGH, Van der Paardt M, Festen CCS, Van Oosterhout MJW, Van Dijk JL, Van der Weijden T, Gansevoort RT, Dasselaar JJ, Van Zoest F, Drenthen T, Walma EP, Goudswaard AN. NHG-Standaard PreventieConsult module Cardiometabool Risico. Huisarts Wet2011:54(3):138-55.

Dijk FJH van, Dormolen M van, Kompier MAJ, Meijman TF. Herwaardering model belasting-belastbaarheid. Tijdschrift voor Sociale Gezondheidszorg 1990; 68 (1): 3-10. 
Duin C van, Garssen J. Bevolkingsprognose 2010-2060: sterkere vergrijzing, langere levensduur. Den Haag/Heerlen: CBS, 2011.

EL\&I. Ministerie van Economische Zaken, Landbouw en Innovatie. Naar de top. Het bedrijvenbeleid in actie(s). Den Haag: Ministerie van EL\&I, 2011.

ERC. Report of the External Review Committee on the 2004-2009 evaluation of CAPHRI. Maastricht: Maastricht UMC+, 2011.

(http://www.caphri.nl/data/files/alg/id277/CAPHRI_ERC-REPORT_TOTAAL.pdf; geraadpleegd op 21 maart 2012)

Fogel RW. The escape from hunger and premature death, 1700-2100. New York: Cambridge University Press, 2004.

Garssen J. Demografie van de vergrijzing. Den Haag/Heerlen: CBS, 2011.

Gedeputeerde Staten van Limburg. Uitvoeringsprogramma 2012 Zorg dichtbij. Betere zorg, begin bij jezelf. Maastricht: Gedeputeerde Staten van Limburg, 2011.

Gemeenten Zuid-Limburg. Een gezonde koers voor Zuid-Limburg! Regionale nota gezondheidsbeleid Zuid-Limburg 2012-2015. Zuid Limburg: Gemeenten ZuidLimburg, 2011.

Gezondheids`raad. Verslag internationale conferentie 'Wat is gezondheid'. Den Haag: Gezondheidsraad, 2010; publicatienr. A10/04.

Gijsen R, Hoeymans N, Schellevis FG, Ruwaard D, Satariano WA, Bos GAM van den. Causes and consequences of comorbidity: a review. Journal of Clinical Epidemiology 2001; 54: 661-674.

Gress S, Baan CA, Calnan M, et al. Co-ordination and management of chronic conditions in Europe: the role of primary care - position paper of the European. Forum for Primary Care. Quality in Primary Care 2009;17:75-86

Gröne O, Garcia-Barbero M. Trends in integrated care - reflections on conceptual issues. EUR/O2/5037864. Copenhagen: World Health Organization, 2002.

Have $\mathrm{H}$ ten. Gezondheid in filosofisch perspectief. Filosofie en praktijk, 1987: 8 (3): $113-127$.

Heuvel WJA van den. De sociale omgeving als determinant van gezondheid en ziekte. In: Maas PJ van der, Hofman A, Dekker E (red.). Epidemiologie en gezondheidsbeleid. Alphen a/d Rijn: Samson Stafleu, 1989: 123-132. 
Hildebrandt H, Hermann C, Knittel R, Richter-Reichhelm M, Siegel A, Witzenrath W. Gesundes Kinzigtal Intgrated Care: improving population health by a shared health gain approach and a shared savings contract. International Journal of Integrated Care 2010; 10.

(http://www.ijic.org/index.php/ijic/article/view/539; geraadpleegd op 17 maart 2012)

Hirasing RA, Reeser HM, Groot RRM, Ruwaard D, Buuren S van, Verloove-Vanhorick SP. Trends in hospital admissions among children aged o-19 years with type I diabetes in the Netherlands. Diabetes Care 1996; 19: 431-434.

Hoeymans N, Melse JM, Schoemaker CG. Gezondheid en determinanten. Deelrapport van de VTV 2010. Van gezond naar beter. Rijksinstituut voor Volksgezondheid en Milieu. Houten: Bohn Stafleu Van Lochum, 2010.

Hoeymans N, Schellevis FC. Selectie van chronische ziekten. In: Volksgezondheid Toekomst Verkenning, Nationaal Kompas Volksgezondheid. Bilthoven: RIVM, $\langle$ ttp://www.nationaalkompas.n/> Nationaal Kompas Volksgezondheid Gezondheid en ziekte\Ziekten en aandoeningen \Chronische ziekten en multimorbiditeit, 12 december 2008. Nationaal Kompas Volksgezondheid, versie 4.5, 22 september 2011.

Hollander AEM de, Hoeymans N, Melse JM, Oers JAM van, Polder JJ (red.). Zorg voor gezondheid. Volksgezondheid Toekomst Verkenning 2006. Rijksinstituut voor Volksgezondheid en Milieu. Houten: Bohn Stafleu Van Lochum, 2006.

Horst A van der, Erp F van, Jong J de. Trends in gezondheid en zorg. Den Haag: Centraal Planbureau, 2011.

Houtum WH van, Rauwerda JA, Ruwaard D, Schaper NC, Bakker K. Reduction in diabetes related lower extremity amputations in the Netherlands: 1991-2000. Diabetes Care 2004; 27:1042-1046.

Huber M, Knottnerus JA, Green L, et al. How should we define health? BMJ 2011; 343: $\mathrm{d} 4163$.

IRI. International Research Institutes. Global Health Survey, 2011. Experience \& perception in 28 countries, 2011.

(http://www.irisnetwork.org; geraadpleegd op 17 maart 2012)

Jansen MW, Ruwaard D. Making an impact instead of 'publish or perish'. The European Journal of Public Health 2012; doi: 10.1093/eurpub/cksO23

Kentikelenis A, Karanikolos M, Papanicolas I, Basu S, McKee M, Stuckler D. Health effects of financial crisis: omens of a Greek tragedy. The Lancet; 378: 1457-1458.

KNMG. Sterke medische zorg voor kwetsbare ouderen. KNMG-standpunt. Utrecht: KNMG, 2010. 
Kodner DL, Spreeuwenberg C. Integrated care: meaning, logic, applications, and implications - a discussion paper. International Journal of Integrated Care, 2002; 2: 14e. (http://www.ijic.org/index.php/ijic/article/view/URN\%3ANBN\%3ANL\%3AUI\% 3A10-1-100309/133; geraadpleegd op 17 maart 2012)

Kompas voor samenwerking in Zuid-Limburg. Strategisch Ontwikkelingsprogramma Zuid-Limburg, 7 juli 2011. (http://www.hitfoundation.eu/docs/Kompas\%20voor\%20samenwerking\%20 in\%20Zuid-Limburg.pdf; geraadpleegd op 17 maart 2012)

Kümpers SNS. Steering integrated care in England and The Netherlands: the cae of dementia care. Maastricht: thesis, 2005.

Lalonde M. A new perspective on the health of the Canadians. Ottawa: Ministery of National Health and Welfare, 1974.

Latta JM. Het preventieconsult. Diemen: CVZ, 2011.

(http://www.cvz.nl/binaries/live/cvzinternet/hst_content/nl/documenten/standpunten/2011/sp1110-preventieconsult-v2.pdf; geraadpleegd op 17 maart 2012)

Leichsenring K, Alaszewski AM (eds.). Providing integrated and socoal care for older persons. A European overwiew of issues at stake. Austria, Vienna: European Centre Vienna, 2004.

Lezwijn J, Vaandrager L, Naaldenberg J, Wagemakers A, Koelen M, Woerkum C van. Healthy ageing in a salutogenic way: building the HP 2.0 framework. Health \& Social Care in the Community 2011; 19: 43-51.

Linden BA van der, Spreeuwenberg C, Schrijvers AJ. Integration of care in The Netherlands: the development of transmural care since 1994. Health Policy 2001; 55: 111-20.

Lucht F van der, Polder JJ. Van gezond naar beter. Kernrapport Volksgezondheid Toekomst Verkenning 2010. Rijksinstituut voor Volksgezondheid en Milieu. Houten: Bohn Stafleu Van Lochum, 2010.

Luijben AHP, Kommer GJ. Tijd en toekomst. Deelrapport van de VTV 2010. Van gezond naar beter. Rijksinstituut voor Volksgezondheid en Milieu. Houten: Bohn Stafleu Van Lochum, 2010.

Maarse $\mathrm{H}$. Markthervorming in de zorg. Een analyse vanuit het perspectief van de keuzevrijheid, solidariteit, toegankelijkheid, kwaliteit en betaalbaarheid. Maastricht: Universitaire Pers Maastricht, 2011. 
Maastricht UMC+. Heel de mens. Better health in a changing world. Nota Strategisch Beleid. Maastricht UMC+ 2010-2015. Maastricht: Maastricht UMC+, 2010.

Mackenbach JP. Ziekte in Nederland. Volksgezondheid tussen biologie en politiek. Amsterdam: Mouria en Elsevier gezondheidszorg, 2010.

McClellan M, McKethan AN, Lewis JL, Roski J, Fisher ES. A national strategy to put accountable care into practice. Health Affairs 2010; 29: 982-990.

Meerding WJ, Polder JJ, Hollander AEM de, Mackenbach JP. Hoe gezond zijn de zorguitgaven? De kosten en opbrengsten van gezondheidszorg bij infectieziekten, kankers en hart- en vaatziekten - Zorg voor euro's - 6. RIVM-rapport: 270091002. Bilthoven: Rijksinstituut voor Volksgezondheid en Milieu, 2007.

Mur-Veerman I, Raak A van, Paulus A. Comparing integrated care policy in Europe: does policy matter? Health Policy 2008; 85: 172-184.

NDF. Nederlandse Diabetes Federatie. NDF zorgstandaard. Transparantie en kwaliteit van diabeteszorg voor mensen met diabetes type. Amersfoort: NDF, 2007.

NDF. Nederlandse Diabetes Federatie. Convenant. Diabetes, hart- en vaatziekten en obesitas gezamenlijk aangepakt. 2011.

(http://www.diabetesfederatie.nl/nieuws/diabetes-hart-en-vaatziekten-en-obesitas-gezamenlijk-aang-2.html; geraadpleegd op 17 maart 2012)

NPCF. Nederlandse Patiënten Consumenten Federatie. Factsheet Chronische Zorg. Utrecht: NPCF, 2012.

(http://www.npcf.nl/index.php?option=com_content\&view=article\&id=4152:fact sheet-chronische-zorg\&catid=25:eerstelijnszorg; geraadpleegd op 17 maart 2012)

OECD Health data, 2011.

(http://www.oecd.org/document/16/0,3746 en_2649_33929_2085200_1_1_1_1, o.html; geraadpleegd op 17 maart 2012)

Pomp M. Een beter Nederland. De gouden eieren van de gezondheidszorg. Amsterdam: Uitgeverij Balans, 2010.

Poos MJJC (RIVM). Neemt de levensverwachting toe of af? In: Volksgezondheid Toekomst Verkenning, Nationaal Kompas Volksgezondheid. Bilthoven: RIVM, $\langle h t t p: / / w w w . n a t i o n a a l k o m p a s . n /\rangle$ Nationaal Kompas Volksgezondheid Gezondheid en ziektelSterfte, levensverwachting en DALY's \Levensverwachting, 11 december 2011. Nationaal Kompas Volksgezondheid, versie 4.6, 15 december 2011. 
Porter ME, Teisberg EO. Redefining health care. Creating value-based competition on results. Harvard: Harvard Business Press, 2006.

Post NAM, Zwakhals SLN, Polder JJ. Maatschappelijke baten. Deelrapport van de VTV 2010 Van gezond naar beter. Rijksinstituut voor Volksgezondheid en Milieu. Houten: Bohn Stafleu Van Lochum, 2010.

Postma MJ, Ruwaard D, Jager JC, Dekkers ALM. Projecting utilization of hospital in-patient days in The Netherlands: a time-series analysis. IMA Journal of Mathematics Applied in Medicine \& Biology 1995; 12: 185-202.

PRV Limburg. Limburg op leeftijd. Zorg en ondersteuning in tijden van bevolkingskrimp. Advies over de toekomst van zorg en voorzieningen voor ouderen. Maastricht: Provinciale Raad voor de Volksgezondheid Limburg, 2011.

Raak A van, Mur-Veerman I, Hardy B, Steenbergen M, Paulus A (eds.). Integrated care in Europe. Description and comparison of integrated care in six EU countries. Maarssen: Elsevier gezondheidszorg, 2003.

RGP. Regional Geriatric Program of Toronto, 2012. (http://rgp.toronto.on.ca/; geraadpleegd op 17 maart 2012)

Rijksoverheid. Miljoenennota 2012. Tweede Kamer, vergaderjaar 2011-2012, 33 000, nr. 1. 's Gravenhage: Rijksoverheid, 2011.

RIVM. Kosten van ziekten in Nederland 2005. Bilthoven: RIVM, 2005.

Rosen R, Mountford J, Lewis G, Lewis R, Shand J, Sha S. Integration in action: four international case studies. London: Nuffield Trust, 2011.

(http://www.nuffieldtrust.org.uk/sites/files/nuffield/integration-in-actionresearch-report-jul11.pdf; geraadpleegd op 17 maart 2012)

Rosendal H, Ahaus K, Huijsman R, Raad C (red.). Ketenzorg. Praktijk in perspectief. Maarssen: Elsevier gezondheidszorg, 2009.

Ruwaard D. Kramers PGN (eindred.) Volksgezondheid Toekomst Verkenning. De gezondheidstoestand van de Nederlandse bevolking in de periode 1950-2010. Rijksinstituut voor Volksgezondheid en Milieuhygiëne. Den Haag: Sdu Uitgeverij, 1993.

Ruwaard D, Hoogenveen RT, Verkleij H, Kromhout D, Casparie AF, Veen EA van der. Forecasting the number of diabetic patients in the Netherlands in 2005. American Journal of Public Health 1993; 83: 989-995.

Ruwaard D, Hirasing RA, Reeser HM, Bakker K, Heine RJ, Geerdink RA, Bruining GJ, Vaandrager GJ, Verloove-Vanhorick SP. Increasing incidence of Type I diabetes mel- 
litus in the Netherlands: the second nation-wide study among children under 20 years of age. Diabetes Care 1994; 17: 599-601.

Ruwaard D, Gijsen R, Bartelds AIM, Hirasing RA, Verkleij H, Kromhout D. Is the incidence of diabetes increasing in all age-groups in The Netherlands? Results of the second study in the Dutch Sentinel Practice Network. Diabetes Care 1996a; 19: $214-218$.

Ruwaard D. Diabetes mellitus: from epidemiology to health policy. Thesis. Rotterdam: Erasmus University, 1996 b.

Ruwaard D, Kramers PGN (eindred.). Volksgezondheid Toekomst Verkenning 1997. De som der delen. Rijksinstituut voor Volksgezondheid en Milieu. Utrecht: Elsevier/De Tijdstroom, 1997

Ruwaard D, Kramers PGN. Health reporting in European Perspective: the Dutch example. The European Journal of Public Health 2000; 10: 83-85.

RVZ. Raad voor de Volksgezondheid en Zorg. Zorg voor je gezondheid. Gedrag en gezondheid: nieuwe ordening. Den Haag: Raad voor de Volksgezondheid en Zorg, 2010a.

RVZ. Raad voor de Volksgezondheid en Zorg. Perspectief op gezondheid 20/20. Den Haag: Raad voor de Volksgezondheid en Zorg, 2010 b.

Schlette S, Lisac M, Blum K. Integrated primary care in Germany: the road ahead. International Journal of Integrated Care 2009 Apr 20;9. (http://www.ijic.org/ index.php/ijic/article/view/311; geraadpleegd op 17 maart 2012)

Schoen C, Osborn R, Huynh PT, et al. On the front lines of care: primary care doctors' office systems, experiences, and views in seven countries. Health Affairs 2006; 25: W555-w571.

Schoen C, Osborn R, Doty MM, et al. Toward higher-performance health systems: adults' health care experiences in seven countries, 2007. Health Affairs 2007; 26: w717-w734.

Schoen C, Osborn R, How SKH, et al. In chronic condition: experiences of patients with complex health care needs, in eight countries, 2008. Health Affairs 2008; 28: w1-w16.

Schoen C, Osborn R, Doty MM, et al. A survey of primary care physicians in eleven countries, 2009: perspectives on care, costs, and experiences. Health Affairs 2009; 28: W1171-W1183.

Schoen C, Osborn R, Squires D, et al. How health insurance design affects access to care and costs, by income, in eleven countries. Health Affairs 2010; 29: 2323-2334. 
Schoen C, Osborn R, Squires D, et al. New 2011 survey of patients with complex care needs in eleven countries finds that care is often poorly coordinated. Health Affairs 2011; 30: 2437-2448.

Shih A, Davis K, Schoenbaum S, Gauthier A, Nuzum R and McCarthy D. Organising the US health care delivery system. New York: Commonwealth Fund, 2008.

Spijkerman A, Dekker J, Nijpels G, Adriaanse M, Kostense P, Ruwaard D, Stehouwer C, Bouter L, Heine R. Microvascular complications at the time of diagnosis of type 2 diabetes are similar among diabetic patients detected by targeted screening and newly diagnosed diabetic patients in general practice. The Hoorn screening study. Diabetes Care 2003; 26: 2604-2608.

Spijkerman AMW, Henry RMA, Dekker JM, Nijpels G, Kostense PJ, Kors JA, Ruwaard D, Stehouwer CDA, Bouter LM, Heine RJ. Prevalence of macrovascular disease amongst type 2 diabetic patients detected by targeted screening and patients newly diagnosed in general practice: the Hoorn Screening Study. Journal of Internal medicine 2004; 256: 429-436.

Stange KC. The problem of fragmentation and the need for integrative solutions. Annals of Family Medicine 2009; 7: 100-103.

Steering Committee on Future Health Scenarios. Chronic Diseases in the year 2005. Volume 1: Scenarios on Diabetes Mellitus 1990 2005. Kluwer Academic Publishers, Dordrecht Boston London, 1991.

Steering Committee on Future Health Scenarios. Chronic Diseases in the year 2005. Volume 2: Scenarios on Chronic Non-Specific Lung Diseases 19902005. Kluwer Academic Publishers, Dordrecht Boston London, 1993.

Steering Committee on Future Health Scenarios. Chronic Diseases in the year 2005. Volume 3: Scenarios on Rheumatoid Arthritis 1990 2005. Kluwer Academic Publishers, Dordrecht Boston- London, 1994.

STG. Stuurgroep Toekomstscenario's Gezondheidszorg. Chronische ziekten in het jaar 2005. Deel 4: Scenario's voor beleid. Bohn Stafleu van Loghum, Houten/ Antwerpen, 1992.

Stivoro. Stivoro voor een rookvrije toekomst. Den Haag: Stivoro, 2012. (http://www.stivoro.nl/Over_STIVORO/Nieuws_persberichten/Persberichten/index. aspx; geraadpleegd 17 maart 2012)

Stolz W. Gevangen in de zorgketen. Verslag van een dwaaltocht door de gezondheidszorg. Delft: Eburon Uitgeverij, 2011. 
Stuckler D, Meissner CM, King LP. Can a bank crisis break your heart? Globalization and Health 2008; 4 (http://www.globalizationandhealth.com/content/4/1/1; geraadpleegd op 17 maart 2012)

Tinetti ME, Studenski SA. Comparative effectiveness research and patients with multiple chronic conditions. N Engl J Med 364: 26: 2478-2480.

Verweij A, Lucht F. van der. Gezondheid in krimpregio's. Rapport 270171003/2011. Bilthoven: Rijksinstituut voor Volksgezondheid en Milieu, 2011.

Vierhout WPM, Knottnerus JA, Ooij A van, Crebolder HFJM, Pop P, WesselinghMegens AMK, Beusmans GHMI. Effectiveness of joint consultation sessions of general practitioners and orthopaedic surgeons for locomotor-system disorders. The Lancet 1995; 346: 990-994.

Vrijhoef. HJM. Chronische zorg in Nederland anno 2010: leidt verandering tot verbetering? TSG 2010; 88: 59-62.

Vrijhoef HJM, \& Fiolet JFBM. Transmurale zorg: het Chronic Care Model in de praktijk. 10 jaar Transmurale Zorg. Maastricht: Maastricht UMC+ Transmurale Zorg, 2011.

Wagner EH, Austin BT, Von Korff M. Organizing care for patients with chronic illness. Milbank O. 1996; 74: 511-544.

Westert GP, Berg MJ van den, Zwakhals SLN, Heijink R, Jong JD de, Verkleij H. Zorgbalans 2010. Op hoofdlijnen. Bilthoven: RIVM, 2010.

VWS.Zorg die werkt: de beleidsdoelstellingen van de minister van Volksgezondheid, Welzijn en Sport (VWS), kenmerk MC-U-3048431. Den Haag: Ministerie van VWS, $2011 a$.

(http://www.rijksoverheid.nl/documenten-en-publicaties/kamerstukken/2011/ 01/26/zorg-die-werkt-de-beleidsdoelstellingen-van-de-minister-van-volksgezondheid-welzijn-en-sport.html; geraadpleegd op 17 maart 2012)

VWS. Vertrouwen in de zorg: de beleidsdoelstellingen van de staatssecretaris van Volksgezondheid, Welzijn en Sport (VWS), kenmerk: MEVA/AEB-3048722. Den Haag: Ministerie van VWS, 2011 .

(http://www.rijksoverheid.nl/ministeries/vws/documenten-en-publicaties/kamerstukken/2011/01/28/vertrouwen-in-de-zorg-de-beleidsdoelstellingen-van-de-staatssecretaris-van-volksgezondheid-welzijn-en-sport.html; geraadpleegd op 17 maart 2012)

VWS. Landelijke nota gezondheidsbeleid. Gezondheid dichtbij. Kenmerk: VGP/GL 3061852. Den Haag: Ministerie van VWS, 2011c.

(http://www.rijksoverheid.nl/documenten-en-publicaties/notas/2011/05/25/ landelijke-nota-gezondheidsbeleid.html; geraadpleegd op 17 maart 2012) 
VWS. Programmabrief langdurige zorg. Kenmerk: DLZ/KZ-U-3067294. Den Haag: Ministerie van VWS, 2011d.

(http://www.rijksoverheid.nl/documenten-en-publicaties/kamerstukken/ 2011/06/01/programmabrief-langdurige-zorg.html; geraadpleegd op 17 maart 2012)

VWS. Kamerbrief Zorg en ondersteuning in de buurt. Den Haag: Ministerie van VWS, 2011e.

(http://www.rijksoverheid.nl/documenten-en-publicaties/kamerstukken/ 2011/10/14/kamerbrief-zorg-en-ondersteuning-in-de-buurt.html; geraadpleegd op 17 maart 2012)

Woittiez I, Eggink E, Jonker J-J, Sadiraj K. Vergrijzing, verpleging en verzorging. Ramingen, profielen en scenario's 2005-2030. Den Haag: Sociaal en Cultureel Planbureau, 2009.

WVC. Nota 2000. Over de ontwikkelingen van gezondheidsbeleid: feiten, beschouwingen en beleidsvoornemens. Tweede Kamer, vergaderjaar 1985-1986, 19500, nrs. 1-2. Rijswijk: Ministerie van WVC, 1986. 
